\title{
The Doctrine of Forum Non Conveniens
}

\author{
Edward L. Barrett, Jr.*
}

$T_{\text {civil action frequently conflict. The defendant, for obvious and }}$ legitimate reasons, will usually prefer to be sued where he resides or where the facts giving rise to the plaintiff's cause of action occurred. But a rule so limiting the venue of actions would permit the defendant to avoid his obligations in many cases by the simple expedient of permanently removing himself and his property from the jurisdiction of the courts of the states where the venue is laid. The patent injustice of such a result has led common-law courts to devise venue rules designed primarily to assist the plaintiff in his pursuit of an elusive defendant. ${ }^{1}$

Under these venue rules actions relating to real property are local and must be brought where the land lies. ${ }^{2}$ But substantially all other actions are transitory and may be sued upon wherever the defendant can be found and subjected to the jurisdiction of the court. ${ }^{3}$ Frequently, therefore, the plaintiff has a choice of several forums in which to sue since today a defendant often may be subjected to the

*B.S. Utah State Agricultural College, 1938; LL.B. University of California, 1941; Lecturer in Jurisprudence and Secretary of the Faculty of Jurisprudence, University of California.

1 Scott, Fundamentals of Procedure in Actions at Latw (1922) c. 1; Foster, Place of Trial in Civil Actions (1930) 43 Harv. L. Rev. 1217, 44 ibid. 41; Kuhn, Local and Transitory Actions in Private International Law (1918) 66 U. OF PA. L. REv. 301; Storke, Venue of Actions of Trespass to Land (1921) 27 W. VA. L. Q. 301; Wheaton, Nature of Actions-Local and Transitory (1922) 16 Irc. L. REv. 456.

The traditional attitude of the courts was best expressed in Barrell v. Benjamin (1819) 15 Mass. 354, 357, where a Connecticut resident served a Demerara resident in Boston when he was there to board ship en route to Demerara and was permitted to recover a personal judgment on a cause of action which arose in Demerara: "It is true that the debtor may be put to inconvenience by being obliged to answer in a foreign country. But the creditor may also be put to inconvenience if he should be denied the privilege of suing in a foreign court; for the debtor may withdraw his person and effects froun the place of his business; and if he cannot be pursued, may defraud his creditor of his due." See also Roberts v. Dunsmuir (1888) 75 Cal. 203, 16 Pac. 782.

2 In these actions the plaintiff can usually satisfy his demands even though the court does not have personal jurisdiction of the defendant, with the exception, of course, of actions for trespass to land when they are considered local. See authorities cited in note 1, supra.

${ }^{3}$ Stone v. United States (1897) 167 U. S. 178. 
jurisdiction of many courts. Individuals may travel widely in the normal course of business and therefore be subject to personal service in many states. And corporations, which once were thought to dwell only in the states of their mcorporation, ${ }^{4}$ may now be sued on transitory causes of action in any state $m$ which they do a substantial amount of business ${ }^{\mathrm{b}}$ or in which they have expressly consented to such suits as a condition of doing business. ${ }^{\circ}$

The plaintiff's right to choose jurisdictions in which to sue, however, has often imposed an unnecessary and harsh burden on the defendant who is making no effort to avoid his obligations. Numerous difficulties are involved in defending a suit at a place other than the residence of the defendant or the locality where the cause of action arose. ${ }^{7}$ Personal attendance of witnesses may not be coinpelled across state hines. ${ }^{8}$ The expense of transporting voluntary witnesses or business records may be out of proportion to the amount in suit. Necessary witnesses may be the defendant's key einployees whose absence would

4 Bank of Augusta v. Earle (1839) 38 U. S. (13 Pet.) 519; Henderson, THE Posr-

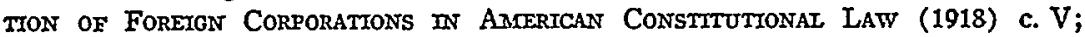
McGovney, A Supreme Court Fiction: Corporations in the Diverse Citizenship Jurisdiction of the Federal Courts (1943) 56 HaRv. L. Rev. 853, 1090, 1225.

6 Under recent cases corporations may be sued in any state in which they do business on causes of action arising out of that business. International Shoe Co. v. State of Washington (1945) 326 U.S. 310; McBaine, Jurisdiction Over Foreign Corporations: Actions Arising Out of Acts Done Within the Forum (1946) 34 CaLIF. L. Rev. 331. And, while the cases are not entirely clear, there appears to be hittle doubt that service of process upon an actual agent of a foreign corporation which is doing substantial business in the state is sufficient to give jurisdiction of an action arising outside the state. See Railroad Co. v. Harris (1870) 79 U.S. (12 Wall.) 65 ; New York, Lake Erie \& W. R. Co. v. Estill (1893) 147 U. S. 591 ; Missouri, K. \& T. Ry. Co. v. Reynolds (1921) 255 U. S. 565, aff'g Reynolds v. Missouri, K. \& T. Ry. Co. (1917) 228 Mass. 584, 117 N. E. 913 ; International Shoe Co. v. State of Washington, supra, at 318; MCBAINE, CAses on TRIAI Practice (2d ed. 1941) 134, n.; Note (1936) 45 Yale L. J. 1100, 1114. But cf. Old Wayne Life Ass'n v. McDonough (1907) 204 U. S. 8; Simon v. Southern Ry. Co. (1915) 236 U.S. 115; Davis v. Farmers Co-operative Co. (1923) 262 U.S. 312.

6 Pennsylvania Fire Ins. Co. v. Gold Issue Mining Co. (1917) 243 U. S. 93 ; Smolik v. Philadelphia \& Reading Coal \& Iron Co. (S. D. N. Y. 1915) 222 Fed. 148; McBanNE, loc. cit. supra note 5; Note (1936) 45 YALE L. J. 1100, 1112. The filing of an actual consent to be sued pursuant to state statute is now construed as a consent to be sued in the federal as well as the state courts and thus constitutes a waiver of the federal venue requirements. Neirho Co. v. Bethlehem Corp. (1939) 308 U.S. 165. Apparently this extends to permitting suit in the federal court upon causes of action arising outside the state. See Gulf Oil Corp. v. Gilbert (1947) 330 U. S. 501.

7 See Gulf Oil Corp. v. Gilbert, ibid. at 508, quoted infra.

${ }^{8}$ See 8 WIGIORE, EvIENCE (3d ed. 1940) $\$ 2195 \mathrm{a}$. The alternative of trial upon deposition is obviously of limited usefulness, particularly in personal injury actions. 
interfere with the business as would the absence of essential records. ${ }^{0}$ In other cases a view of the place where the action arose may be essential to a proper understanding of a defense. These and similar factors frequently have made it profitable for a plaintiff with a doubtful or speculative cause of action to select the forum most inconvenient to the defendant so as to coerce a larger settlement than the merits of his case would warrant..$^{10}$

The railroads, in particular, have long complained of the burden of defending suits for personal injuries brought by employees under the Federal Employers' Liability Act ${ }^{11}$ in states far removed from the place of injury. During World War I the burden on the railroads became so great that the Director General of Railroads issued orders requiring suit to be brought in the county or district where the cause of action arose or where the plaintiff resided at the time it accrued. ${ }^{12}$ With the return of the railroads to private hands the practice of suing in distant jurisdictions was revived ${ }^{13}$ and today is so wide-

${ }^{9}$ For a detailed picture of the difficulties facing a defendant see Heine v. New York Life Ins. Co. (C.C.A. 9th, 1931) 50 F. (2d) 382 (burden of transporting records in contract action) ; Union Pac. R. Co. v. Utterback (1944) 173 Ore. 572, 146 P. (2d) 76 (burden of transporting witnesses in tort action).

10 See authorities cited in note 9 , supra, and notes $13,14,16$, infra.

1135 STAT. (1908) 65,45 U.S. C. (1940) §51. The statute provides that suit may be brought in the federal or the state court in the district of the residence of the defendant, or in which the cause of action arose, or in which the defendant shall be doing business at the time of commencing the action. 36 STAT. (1910) 291, 45 U. S. C. (1940) \& 56. For a discussion of the history and purposes of this venue section see Baltimore $\&$ Ohio R. Co. v. Kepner (1941) 314 U.S. 44; Miles v. Mlinois Central R. Co. (1942) 315 U.S. 698 ; Note (1930) 39 YaLe L. J. 388.

12 General Orders No. 18 and 18A, upheld in Alabama etc. Ry. Co. v. Journey (1921) 257 U.S. 111.

13 The worst offenses were in Minnesota where it had previously been held that the courts had no discretion to refuse to hear such suits. State ex rel. Prall v. District Court (1914) 126 Minn. 501, 148 N. W. 463; Davis v. Minneapolis, St. P. \& S. S. M. Ry. Co. (1916) 134 Minn. 455,159 N.W. 1084. In 1923, 1,028 personal injury cases were pending in the Minnesota courts in which nonresident plaintiffs were seeking damages aggregating some $\$ 26,000,000$ from foreign railroad corporations which did not even operate lines in the state. See Davis v. Farniers Co-operative Co., supra note 5, at 316, n. In Winders v. Ilinois Central R. Co. (1929) 177 Minn. 1, 5, 223 N. W. 291, 292, 226 N.W. 213, the court held: "The trial court rightly refused to dismiss the action even though convinced that plaintiff had retained his attorneys under a champertous agreement, or that they are, by illegal methods, obtaining cases for prosecution in this state which in fairness ought to be tried elsewhere." Cf. Chicago, M., St. P. \& P. R. Co. v. Wolf (1929) 199 Wis. 278, 226 N. W. 297, criticizing the Winders case. For other Mimiesota cases permitting such suits against railroads, see Erving v. Chicago \& North Western Ry. Co. (1927) 171 Minn. 87, 214 N. W. 12 ; Boright v. Chicago, R. I. \& P. R. Co. (1930) 180 Minn. 52, 230 N. W. 457; Hoch v. Byram (1930) 180 Minn. 298, 230 N. W. 823; see also Doyle v. Northern Pac. Ry. Co. (D. Minn. 1932) 55 F. (2d) 708, (1933) 46 HArv. L. Rev. 521. 
spread $^{14}$ that the railroads are petitioning Congress for relief. ${ }^{15}$ Furthermore the organized bar has become aroused by the opportunity afforded unethical lawyers to solicit such causes of action arising in outlying areas for suit in large cities by promises of more liberal settlements or larger verdicts. ${ }^{16}$ It has become apparent that under modern conditions "the open door may admit those who seek not

$14 \mathrm{~A}$ survey conducted by 51 leading railroads showed that during a five year period ending in 1946 some 2,512 suits were filed outside the federal district in which the accident occurred or in which the plaintiff resided at the time of the accident and that $92 \%$ of these suits were concentrated in the states of Illinois, New York, Minnesota, Missouri and California. H. R. REP. No. 613, 80th Cong. 1st Sess. (1947), at 3; statement of John W. Freels, representing the Law Committee of the Association of American Railroads, Hearings Before Subcomaititee No. 4, Committee on the Judictary, House of Representatives, on H.R. 1639, 80th Cong. 1st Sess. (1947) Serial 4, at 31.

See generally Henderson, The "Exportation" of Personal Injury and Death Claims (1945) 13 DETRoIt BAR Q. 11; Winters, Interstate Commerce in Damage Suits (1946) 29 J. AM. JUD. Soc. 135; Note (1930) 39 Yale L. J. 388.

$15 \mathrm{H}$. R. 1639, 80th Cong. 1st Sess. (1947) a bill designed to limit the venue of personal injury actions against railroads, was passed by the House of Representatives July 17,1947 , but has not been acted upon by the Senate. See note 29 , infra. The railroads have taken a very strong position in support of this measure. See HEARINGS BEFore SUBCOAnITTEe No. 4, op. cit. supra note 14, at 24 ; H. R. REP. No. 613, loc. cit. supra note 14 .

16 Major support for H. R. 1639, supra note 15, came from the legal profession. Its author, Hon. John Jennings, Jr., United States Representative from Tennessee, testified that the purpose of the act was to do two things: "It is to avoid the inconvenience to carriers which run through many States, and it is to stop this racketeering practice which has grown up to the prejudice of the profession, and the injustice that is done to legitimate lawyers, lawyers who observe the canons, the ethics, the decencies and high requirements of the profession, who have been deprived of this litigation." HEARINGS BEFORE Subcommarime No. 4, op. cit. supra note 14, at 5. The American Bar Association and the bar associations of 35 states passed resolutions approving H. R. 1639. H. R. REP. No. 613 , op. cit. supra note 14 , at 2 . See also Henderson and Winters, both loc. cit. supra note 14.

The most extreine example of unethical practice is presented in injunction suits against a Chicago lawyer now pending in the Superior Court of Cook County, Illinois. The Atchison, Topeka \& S. F. Ry. Co. v. Andrews, No. 46 S 4586; Southern Pacific Co. v. Andrews, No. $46 \mathrm{~S} 9155$. The proof in these cases is said to have shown that the lawyer organized an elaborate procurement staff of some 25 or 30 chasers with headquarters in a Los Angeles mansion to induce railroad employees injured in Arizona, California, and New Mexico to bring their cases to him for suit in Chicago courts; that in a year's time he filed 100 suits in Chicago on foreign causes of action against the two railroads for a total alleged liability of over $\$ 6,000,000$. See testimony of Floyd E. Thompson, attorney for the plaintiffs in these cases, in HEARINGS Before SuBCOMMITTEE No. 4, op. cit. supra note 14, at 18, 19. The complaint in the Santa Fe case contains a tabulation showing that in the period from September, 1945, through March, 1946, the attorney filed 40 suits against the Santa Fe based on injuries which occurred in Arizona, California, and New Mexico for a total alleged liability of $\$ 2,060,000$. The average mileage via Santa Fe from the scene of the accident to Chicago was computed to be 1,930 miles. For other cases giving details of champertous solicitation of litigation against railroads, see Winders v. Mllinois Central R. Co.; Chicago, M., St. P. \& P. R. Co. v. Wolf, both supra note 13. 
simply justice but perhaps justice blended with some harassment". ${ }^{17}$

Courts and legislatures have attempted a number of divergent solutions to the problem thus presented of limiting the plaintiff's choice of forums without permitting the defendant to escape or minimize his obligations. Where the injured party is a resident of the state in which the cause of action arose his prosecution of the action outside that state may be enjoined if it would be vexatious or harassing. ${ }^{18}$ This solution has obvious limitations. ${ }^{10} \mathrm{It}$ is an expensive and wasteful proceeding which requires the parties to try one law suit at home to determine whether another suit abroad shall proceed. Moreover, in the most vexatious cases, where an impecunious plaintiff has left the state at the instigation of a lawyer who is financing the suit, the court may not be able to make the injunction effective..$^{20}$ And the United States Supreme Court has held that such injunctions may not be issued where suit is brought under the Federal Employers' Liability Act. ${ }^{21}$

Another approach to the problem has been to apply a restriction derived from the commerce clause of the United States Constitution. The burden placed upon the efficiency of railroads when their operating employees had to be transported to distant jurisdictions as witnesses induced the United States Supreme Court to apply the commerce clause in Davis v. Farmers Co-operative Co. ${ }^{22}$ The Court held that a state statute permitting suit by a nonresident against a foreign carrier in a state in which the cause of action did not arise and in which the carrier did no business other than the solicitation of traffic unreasonably obstructed and unduly burdened interstate commerce. ${ }^{23}$ The development of this doctrine has been traced in detail elsewhere. ${ }^{2 \mathrm{~A}}$

17 Gulf Oil Corp. v. Gilbert, siepra note 6, at 507 .

18 The cases are reviewed in Note (1941) 27 Iowa L. Rev. 76, 99. See also Messner, The Jurisdiction of a Court of Equity Over Persons To Compel the Doing of Acts Outside the Territorial Limits of the State (1930) 14 MINN. L. REv. 494, 495-506.

19 See the critical discussion in Foster, op. cit. stipra note 1, at 1240.

20 Since the injunction operates only on the person of the defendant, it may be disregarded by the foreign court. Foster, op. cit. supra note 1, at 1240; Note (1941) 27 Iowa L. Rev. 76, 78-81.

21 Baltimore \& Ohio R. Co. v. Kepner; Miles v. Mlinois Central R. Co., both sikpra note 11; see Note (1941) 51 YALE L. J. 343 ; (1942) 27 CoRN. L. Q. 273 ; (1942) 20 N. C. I. REv. 210; (1942) 15 So. CALIr. I. Rev. 482 ; cf. (1940) 46 W. VA. I. Q. 344.

22 Supra note 5.

23 See also Atchison, T. \& S. F. Ry. Co. v. Wells (1924) 265 U. S. 101 ; Missouri v. Taylor (1924) 266 U. S. 200; Hoffman v. Missouri (1927) 274 U. S. 21; Michigan Central v. Mix (1929) 278 U. S. 492 ; Denver \& R. G. W. R. Co. v. Terte (1932) 284 U. S. 284; International Milling Co. v. Columbia Co. (1934) 292 U.S. 511; Note (1936) 104 A. L. R. 1075.

21 Dainow, The Inappropriate Forum (1935) 29 InL. L. REv. 867; Farrier, Sults Against Foreign Corporations as a Burden on Interstate Commerce (1933) 17 MrNa. 
For present purposes it is enough to note that it affords no general solution to the problem. To date only interstate railroads have been permitted to use the commerce clause as a defense $e^{25}$ and then only when suit has been brought by a nonresident ${ }^{26}$ on a foreign cause of action in a state where the carrier did not own or operate railroad lines. ${ }^{27}$

A third approach has been to restrict the venue of transitory actions by statute. Occasionally state statutes have limited the jurisdiction of local courts so that they could not hear suits against foreign corporations on causes of action arising outside the state. ${ }^{28}$ Congress is considering a bill to limit the venue of all actions for wrongful death or personal injuries brought against interstate railroads to the district court or state court of the district or county, respectively, in which the cause of action arose, or in which the injured party resided at the time of the accident. ${ }^{29}$ But the rigidity of such statutes may cause

L. REv. 381 ; Foster, op. cit. supra note 1, at 1232; Note (1936) 34 MICH. L. REv. 979; (1946) 46 Cor. L. Rev. 643.

25 Cases cited in note 23, supra. The International Milling Co. case suggests that the doctrine might be applied to other interstate transportation companies.

26 International Milling Co. v. Columbia Co., supra note 23. But cf. Klepper v. Canadian Pac. Ry. Co. (1946) 271 App. Div. 52, 62 N. X. S. (2d) 627.

2r Hoffinan v. Missouri; Denver \& R. G. W. R. Co. v. Terte, both supra note 23; see Baltimore \& Ohio R. Co. v. Kepner, supra note 11, at 54; Miles v. Mlinois Central $R$. Co., supra note 11 , at 701 .

23 An Ohio statute has been held to prevent bringing suit against transportation companies for personal injuries received outside the state. OHIo ANN. CODE (Throckmorton, 1940) § 11273; Loftus v. Pennsylvania Rd. Co. (1923) 107 Oliio St. 352, 140 N. E. 94.

Prior to 1913 the New York statutes made no provision for suits by a nonresident against a foreign corporation upon a cause of action arising outside the state. N. Y. CoDE Crv. Proc. (1890) §1780; Robinson v. Oceanic Steam Nav. Co. (1889) 112 N. Y. 315, 19 N. E. 625; Gregonis v. Philadelphia \& R. C. \& I. Co. (1923) 235 N. Y. 152, 139 N. E. 223, (1924) 32 A. L. R. 1. See also Gober v. Fed. Life Ins. Co. (1931) 255 Mich. 20, 237 N. W. 32 ; Central R. R. Co. v. Georgia Co. (1890) 32 S. C. 319, 11 S. E. 192.

${ }^{29} \mathrm{H}$. R. 1639, supra note 15 , as passed by the House on July 17,1947 , provides for the amendment of $\S 51$ of the Judicial Code (36 STar. [1911] 1101, 28 U.S.C. [1940] $\S 112$ ) by adding the following paragraph: "A civil suit for damages for wrongful death or personal injuries against any interstate common carrier by railroad may be brought only in a district court of the United States or in a State court of competent jurisdiction, in the district or county (parish), respectively, in which the cause of action arose, or where the person suffering death or injury resided at the time it arose: Provided, That if the defendant cannot be served with process issuing out of any of the courts afore-mentioned, then and only then, the action may be brought in a district court of the United States, or in a State court of competent jurisdiction, at any place where the defendant shall be doing business at the time of the institution of said action." The venue section of the Federal Employers' Liability Act (see supra note 11) would be repealed with the exception of the portion preventing removals from the state to federal courts. 
serious injustice to the plaintiff in the cases where he has entirely legitimate reasons for suing in a state other than that in which the cause of action arose or either party resides. ${ }^{30}$ Consider, for example, the case of a New Jersey resident who is injured while temporarily in California through negligence attributable to a California corporation which also does business in New York but not in New Jersey. It might be quite unreasonable not to allow him to sue in New York but to force him to travel to California to sue. ${ }^{31}$ And there are cases where the convenience of both parties would best be served by trial in a state other than that of the accident or the residence of the plaintiff. For example, if a railroad employee is injured in one state and hospitalized in another, the witnesses who often are most important-those who will testify on the issue of damages-may reside in the latter state. ${ }^{32}$

Another, and it is believed more promising, attempt to solve the problem is being nuade in some jurisdictions by application of the doctrine of forum non conveniens ${ }^{33}$ which will be discussed herein. Even though jurisdiction over the defendant has been obtained, by application of this doctrine trial courts are given a discretionary power to refuse to hear transitory causes of action whenever trial in the forum would be imappropriate. It will be the purpose of this article (1) to determine the extent to which the doctrine of forum non conveniens has been recognized and to discuss constitutional and other limitations on its application in the state and federal courts; and (2) to survey and appraise the operation of the doctrine in the jurisdictions in which it has been accepted.

\section{DEVELOPMENT OF THE DOCTRINE OF Forum Non Conveniens-} CONSTITUTIONAL AND OTHER LIMITATIONS.

The origins of the doctrine of forum non conveniens are obscure. ${ }^{34}$ The term itself appears to have been used first in a series of Scottish

${ }^{30}$ See Foster, op. cit. supra note 1, at 1223 ; Note (1930) 39 YALE L. J. 388, 400.

31 Cf. Barrow Steamship Co. v. Kane (1898) 170 U. S. 100; cases cited in note 149, infra.

32 See statement of Warren $H$. Atherton on behalf of the Brotherhood of Railroad Trainmen, Hearings Before Subcomamittee No. 4, op. cit. supra note 14, at 57; H. R. Rap. No. 613, Part 2, 80th Cong. 1st Sess. (1947), at 2.

Under H. R. 1639, supra note 15 , as passed by the House, the injured employee would be required to sue in the county, if in a state court, or else in the federal district, if in a federal court, in which the injury occurred or in which he resided, even though all the witnesses happened to live in another county or district.

33 For general discussions of the doctrine see Blair, The Doctrine of Fortm Non Conveniens in Anglo-American Law (1929) 29 Cox. L. REv. 1; Dainow, loc. cit. supra note 24 ; Foster, loc. cit. supra note 1.

34 The doctrine does not appear to be directly traceable to Roman or continental 
decisions in the late 1800's to describe what was by then a settled rule of Scottish practice, i.e., trial courts could refuse to hear cases when the ends of justice would best be served by trial in another forum. ${ }^{35}$ In an independent development a few American courts, without benefit of the Latin phrase, early recognized the discretion of trial courts to refuse jurisdiction in certain types of cases. ${ }^{36}$ And in recent years the

practice. See Beale, The Jurisdiction of Courts Over Foreigners (1913) 26 HaRv. L. Rev. 193, 283; Dainow, op. cit. supra note 24, at 881, n.; Lorenzen, The French Rules of the Conflict of Laws (1927) 36 YALE L. J. 731, 744; Pillet, Jurisdiction in Actions Between Foreigners (1905) 18 HaRv. L. Rev. 325. But $c f$. (1943) 56 HaRv. L. Rev. 1162.

35 In a few very early Scottish cases the plea of forum non competens, which normally was directed to a lack of jurisdiction, was sustained in cases where the jurisdiction seemed clear but the parties were nonresidents and trial in Scotland would have been inconvenient. E.g., Vernor v. Elvies (1610) 6 Dict. of Dec. 4788; Col. Brog's Heir v. (1639) 6 Dict. of Dec. 4816; cf. Anderson v. Hodgson (1747) 6 Dict. of Dec. 4779. In later cases the courts expressly recognized that the plea of forum non competens was available both where the court lacked jurisdiction and where it was not expedient for the due administration of justice to hear the case. See Parken v. Royal Exchange Assurance Co. (1846) 8 Sess. Cas. (2d ser.) 365; Longworth v. Hope (1865) 3 Sess. Cas. (3d ser.) 1049, 1053 ("The next question is the question of form non competens. Now the plea usually thus expressed does not mean that the forum is one in which it is wholly incompetent to deal with the question. The plea has received a wide signification, and is frequently stated in reference to cases in which the Court may consider it more proper for the ends of justice that the parties should seek their remedy in another forum."); Clenients v. Macaulay (1866) 4 Sess. Cas. (3d ser.) 583; 7 Encyc. Laws of SCOTLAND (1929) 180.

Thereafter the courts apparently invented the term forum non conveniens to be used instead of forum non competens when the jurisdiction of the court was clear and only a question of discretion was involved. See Brown v. Cartwright (1883) 20 Scot. L. R. 818; Williamson v. North-Eastern Ry. Co. (1884) 21 Scot. L. R. 421; La Société du Gaz de Paris v. La Société Anonyme de Navigation "Les Armateurs français" [1925] Sess. Cas. 332, [1926] Sess. Cas. (H. L.) 13. The Scottish cases are fully dis-

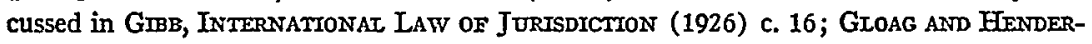

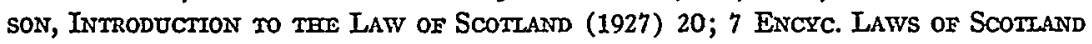
(1929) 180.

36 The earliest cases were suits between ahens on foreign causes of action. See, e.g., Robertson v. Kerr (1793), reported in a note to Rea v. Hayden (1807) 3 Mass. 24, 25; Great Western Ry. Co. v. Miller (1869) 19 Mich. 305; Gardner v. Thomas (N. Y. 1817) 14 Johns. 134, 7 Am. Dec. 445; Johnson v. Dalton (N. Y. 1823) 1 Cow. 543, 13 Am. Dec. 564; Note (1873) 7 Axr. L. Rev. 417; (1933) 13 B. U. L. REv. 349. A similar result was reached in suits between aliens in the federal admiralty courts. The Belgenland (1885) 114 U. S. 355; One Hundred \& Ninety-Four Shawls (S.D. N. Y. 1848) Fed. Cas. No. 10,521; see RoBLnson, Adariralty (1939) § 3; Coffey, Jurisdiction Over Foreigners in Admiralty Courts (1925) 13 CAIIF. L. REv. 93. And in a few cases where the plaintif was a resident of another state of the United States, discretion to refuse jurisdiction was recognized. See Pierce v. Equitable Life Assurance Society (1887) 145 Mass. 56, 12 N. E. 858; Molony v. Dows (1859) 8 Abb. Pr. 316; Ferguson v. Neilson (1890) 11 N. Y. Supp. 524; Morris v. Missouri Pacific Ry. Co. (1890) 78 Tex. 17, 14 S. W. 228. But cf. Beale, op. cit. supra note 34 , at 288 . The cases are collected in Note (1924) 32 A. L. R. 6. 
English courts, relying on both Scottish and American precedents, have accepted the doctrine of forum non conveniens as a means of preventing abuse of the court's process when the plaintiff's choice of forum is vexatious and works unnecessary hardship on the defendant. ${ }^{37}$

In 1929 a law review writer brought the term forum non conveniens into American law, contending that all American courts had inherent power to decline jurisdiction under the doctrine. ${ }^{38}$ After this article the use of the term became so general that in 1941 Justice Frankfurter referred to the "familiar doctrine of forum non conveniens" as a manifestation of a civilized judicial system which is "firmly imbedded in our law". ${ }^{99}$ Yet few American courts have actually accepted the doctrine. In most states it has not even been considered. In others it has been rejected. ${ }^{40}$ And today it can be said to be in opera-

37 In Logan v. Bank of Scotland [1906] I K. B. 141, the court relied upon Collard v. Beach (1903) 81 App. Div. 582, 81 N. Y. Supp. 619, (1904) 93 App. Div. 339, 87 N. Y. Supp. 884; Longworth v. Hope; Williamson v. North-Eastern Ry. Co., both supra note 35. The doctrine has also been apphed in Eghert v. Short [1907] 2 Ch. 205; In re Norton's Settlement [1908] 1 Ch. 471. Prior to the Logan case the Enghish law was dominated by the famous case of Mostyn v. Fahrigas (1775) 1 Cowp. 161, 171, in which Lord Mansfield, in upholding the jurisdiction of the Enghish courts over an action between residents of the Island of Minorca, said: ". . . for it is impossible there ever could exist a doubt, but that a subject born in Minorca has as good a right to appeal to the King's Courts of Justice, as one who is born within the sound of Bow Bell. . . " See Leflar, Extrastate Enforcement of Penal and Govermmental Claims (1932) 46 HaRv. L. Rev. 193. 38 Blair, loc. cit. supra note 33 . He found only three or four cases in which the American courts had used the term.

${ }^{39}$ In his dissenting opinion in Baltimore \& Ohio R. Co. v. Kepner, supra note 11, at 55 .

40 Alabama. Steen v. Swadley (1900) 126 Ala. 616, 28 So. 620; Jefferson Island Salt Co. v. E. J. Longyear Co. (1923) 210 Ala. 352, 98 So. 119. Connecticut. See Fine v. Wencke (1933) 117 Conn. 683, 169 Atl. 58. Illinois. Wintersteen v. National Cooperage Co. (1935) 361 Il. 95, 197 N. E. 578 ; Indiana. Levi v. Kaufman (1895) 12 Ind. App. 347, 39 N. E. 1045 ; Dodgem Corp. v. D. D. Murphy Shows, Inc. (1932) 96 Ind. App. 325, 183 N. E. 699, reh'g den., 96 Ind. App. 325, 185 N. E. 169. Michigan. Cofrode v. Gartner (1890) 79 Mich. 332, 44 N. W. 623. But cf. Goher v. Fed. Life Ins. Co., supra note 28. Minnesota. Boright v. Chicago, R.I.\& P.R. Co., supra note 13. Missouri. Bright v. Wheelock (1929) 323 Mo. 840, 20 S. W. (2d) 684. Nebraska. Herrnann v. Franklin Ice Creain Co. (1926) 114 Neb. 468, 208 N.W. 141. North Carolina. McDonald v. MacArthur Bros. Co. (1910) 154 N. C. 122, 69 S. E. 832. Ohio. Mattone v. Argentina (1931) 123 Ohio St. 393, 175 N. E. 603. Texas. See Allen v. Bass (Tex. Civ. App. 1932) 47 S. W. (2d) 426, 427; H. Rouw Co. v. Railway Exp. Agency (Tex. Civ. App. 1941) 154 S. W. (2d) 143, 145, (1942) 20 TEx. L. REv. 609. Utah. Steed v. Harvey (1898) I8 Utah 367, 54 Pac. 1011. Virginia. Morgan v. Pennsylvania R. Co. (1927) 148 Va. 272, 138 S. E. 566. Wisconsin. Eingartner v. Illinois Steel Co. (1896) 94 Wis. 70, 68 N. W. 664 ; Bourestom v. Bourestom (1939) 231 Wis. 666, 285 N. W. 426. 
tion in barely half a dozen states ${ }^{41}$ and, as a result of decisions handed down only this past term, in the federal courts. ${ }^{42}$

\section{A. State Courts.}

General acceptance of the doctrine of forum non conveniens in the state courts has been retarded more by the privileges and immunities clause of Article IV of the United States Constitution ${ }^{43}$ than by any other factor. In the early case of Corfield $v$. Coryell, ${ }^{44} \mathrm{Mr}$. Justice Washington asserted by dictum that the right of access to the courts of a state is one of the privileges protected by that clause. A long line of cases in which the United States Supreme Court has approved this dictum $^{45}$ leaves little doubt that any arbitrary denial by a state of the

41 Only the following states appear to have accepted the doctrine generally: Florida. See Hagen v. Viney (1936) 124 Fla. 747, 751, 169 So. 391, 392. Louisiana. Union City Transfer v. Fields (La. App. 1940) 199 So. 206; cf. Stewart v. Litchenberg (1920) 148 La. 195, 86 So. 734. Massachusetts. Universal Adjustment Corp. v. Midland Bank (1933) 281 Mass. 303, 184 N. E. 152, 87 A. L. R. 1407. New Hampshire. Jackson \& Sons v. Lumbermen's Mut. Casualty Co. (1933) 86 N.H. 341, 168 Atl. 895. New Jersey. See Kantakevich v. D., L. \& W. R. R. Co. (1940) 18 N. J. Misc. 77, 10 A. (2d) 651; Quigley Co. v. Asbestos Ltd. (1944) 134 N. J. Eq. 312, 35 A. (2d) 432, aff'd, 135 N. J. Eq. 460, 39 A. (2d) 135. New York (limited to tort actions). See Gregonis v. Philadelphia \& R. C. \& I. Co., supra note 28 , at 155,139 N. E. at 226; Murnan v. Wabash Railway Co. (1927) 246 N. Y. $244,248,158$ N. E. 508, 509.

In the following states there are indications that the doctrine might be accepted when a proper case arises: Arkansas. Grovey v. Washington Nat. Ins. Co. (1938) 196 Ark. 697, 119 S. W. (2d) 503. Califormia. Leet v. Union Pac. R. R. Co. (1944) 25 Cal. (2d) 605, 155 P. (2d) 42, 158 A. L. R. 1008; Estate of Knox (1942) 52 Cal. App. (2d) 338, 126 P. (2d) 10S. But cf. Hudson v. Von Hamm (1927) 85 Cal. App. 323, 259 Pac. 374. Iowa. Bradbury v. Chicago, R.I.\& Pac. Ry. Co. (1910) 149 Iowa 51, 128N. W.1. Mississippi. Strickland v. Humble Oil \& Ref.Co. (1943) 194 Miss. 194, 11 So. (2d) 820; Tri-State Transit Co. v. Mondy (1943) 194 Miss. 714, 12 So. (2d) 920. Oregon. Horner v. Pleasant Creek Mining Corp. (1940) 165 Ore. 683, 107 P. (2d) 989. Vermont. Morisette v. Canadian Pacific Railway Co. (1904) 76 Vt. 267, 56 Atl. 1102; Wellman v. Mead (1919) 93 Vt. 322, 107 Atl. 396. Washington. Hunter v. Wenatchee Land Co. (1905) 36 Wash. 541, 79 Pac. 40. But cf. Reynolds v. Day (1914) 79 Wash. 499, 140 Pac. 681.

42 Koster v. Lumbermens Mutual Co. (1947) 330 U. S. 518; Gulf Oil Corp. v. Gilbert, supra note 6.

43 U. S. Const. Art. IV, $\S 2, \mathrm{Cl}$. 1. "The citizens of each State shall be entitled to all privileges and immunities of citizens in the several States."

44 (E.D. Pa. 1823) Fed. Cas. No. 3,230. Justice Washington concluded that only those privileges and immunities of state citizenship which are "in their nature fundanental" were protected by the Constitution. In listing the privileges which he considered fundamental, he included the "right to institute and maintain actions of any kind in the courts of the state". 6 Fed. Cas. at 552.

45 See Ward v. Maryland (1870) 79 U.S. (12 Wall.) 418, 430 (a case involving a discriminatory tax against nonresident traders); Chambers v. Baltimore \& Ohio R. Co. (1907) 20 ' U. S. 142, 148; Canadian Northern Ry. Co. v. Eggen (1920) 252 U. S. 553, 560; Missouri Pac. R. R. Co. v. Clarendon Boat Oar Co. (1922) 257 U.S. 533, 535; 
right of citizens of other states to sue would be held unconstitutional. As a result, many courts held that the privileges and immunities clause precluded any discretionary power in courts to decline suits between nonresidents where the plaintiff was an individual citizen of another state. ${ }^{46}$ In most such cases it was assumed that a resident plaintiff would have an absolute right to sue, and the argument for refusing jurisdiction over nonresidents was directed to the burden on the local courts and taxpayers incident to trial of cases from other states. Therefore, a strong argument could be made that any such exercise of discretion to refuse jurisdiction was a clear violation of the spirit and intent of the constitutional provision. ${ }^{47}$ In New York, ${ }^{48}$ however, the courts took the consistent position that the constitutional provision was not violated since the discrimination was based on residence,

McKnett v. St. Louis \& S.F. Ry. Co. (1934) 292 U. S. 230, 233; Miles v. Mlinois Central R. Co. (1942) 315 U.S. 698, 704.

46 Barrell v. Benjamin, supra note 1 ; Cofrode v. Gartner, supra note 40; State ex rel. Prall v. District Court; Davis v. Minneapolis, St. P. \& S. S. M. Ry. Co.; Erving v. Chicago \& Northwestern Ry. Co., all supra note 13; State v. Grimm (1911) 239 Mo. 135, 143 S. W. 483 ; Herrmann v. Franklin Ice Cream Co.; McDonald v. MacArthur Bros. Co.; Steed v. Harvey; Morgan v. Pennsylvania R. Co., all supra note 40; Reynolds v. Day, supra note 41; Eingartner v. Mlinois Steel Co., supra note 40; see Hudson v. Von Hamm, supra note 41; Fine v. Wencke, supra note 40; Brower v. Watson (1922) 146 Tenn. 626, 244 S. W. 362 ; Deatrick's Adın'r v. State Life Ins. Co. (1907) 107 Va. 602, 59 S. E. 489; State v. Fowler (1928) 196 Wis. 451,220 N. W. 534. See also Blair, op. cit. stupra note 33, at 12 ; Note (1930) 18 CALIF. L. REv. 159.

47 In Cofrode v. Gartner, supra note 40 , which was long a leading case, the trial court justified the exercise of its discretion to refuse to hear a suit brought by a nonresident by a rather detailed showing of the burden which trial of the case would put upon the court and upon the taxpayers of the county. After holding the privileges and immunities clause applicable, the Michigan supreme court said at 343, 44 N.W. at 626: "No court or judge has a lawful right to deny to suitors the privilege of bringing and prosecuting their suits upon the ground that to entertain them will entail expense to the county." In State v. Grimm, supra note 46 , at 184,143 S. W. at 498 , the court said: "It would be both unjust and intolerable for one State of the Union to possess the power and authority to enact a valid statute closing the doors of its courts to citizens of the United States, or of other States, and deny to them the right or privilege of suing in the courts thereof, while the citizens of such State enjoy that right or privilege. To so hold would be not only to nullify the spirit of the provisions of the Federal Constitution previously mentioned [Art. IV, §2 and Amendment XIV, §1], but the letter thereof as well." See also Reynolds v. Day, supra note 41; Eingartner v. Mlinois Steel Co., supra note 40.

$48 \mathrm{By}$ far the greatest number of cases in which a discretion to deny jurisdiction of suits between nonresidents has been exercised are found in the New York courts. This apparently results from a long-standing fear of the burden which would be cast upon the courts if a general right of suit were recognized. See, $6 . g$., the concern over this possibility expressed in Hoes v. New York, N. H. \& H. R. R. Co. (1903) 173 N. Y. 435, 66 N. E. 119; Collard v. Beach, supra note 37 . 
not citizenship, of the parties. ${ }^{49}$ Unrealistic as this distinction was, ${ }^{50}$ it had some support in United States Supreme Court decisions interpreting the privileges and immunities clause ${ }^{51}$ and was apparently adopted by that Court in Douglas v. New Haven R. Co. ${ }^{52}$

In the Douglas case a Connecticut citizen and resident brought suit against a Connecticut corporation in the state courts of New York under the Federal Employers' Liability Act to recover damages for personal injuries suffered in Connecticut. The trial court exercised its discretion under a state statute ${ }^{5 S}$ to refuse jurisdiction and dis-

49 Robinson v. Oceanic Steam Nav. Co., supra note 28; Hatfield v. Sisson (1899) 28 Misc. 255, 256, 59 N. Y. Supp. 73; Collard v. Beach, supra note 37.

This distinction between residence and citizenship was also relied upon in Ohio and South Carolina to sustain statutes denying jurisdiction to local courts of suits by nonresidents against foreign corporations on causes of action arising outside the state. Loftus v. Pennsylvania Rd. Co.; Central R. R. Co. v. Georgia Co., both supra note 28; cf. Cummings v. Wingo (1889) 31 S. C. 427,10 S. E. 107.

50 The distinction between residence and citizenship has long been attacked by commentators. "Possibly before the passage of the Fourteenth Amendment there might have been some ground for this, but in the light of the provision in that Amendment that 'All persons born or naturalized within the United States and subject to the jurisdiction tbereof are citizens of the United States and of the state wherem they reside,' it passes my comprehension how such a contention can for a moment be considered sustainable." Meyers, The Privileges and Immunities of Citizens of the Several States (1903) 1 Mich. L. REv. 364, 382. "The distinction of the New York and South Carolina courts between 'resident' and 'citizen' would, therefore, seem to be merely verbal, and insufficient to support their decisions." (1903) 17 HARv. L. REv. 54, 55.

In Travis v. Yale \& Towne Mfg. Co. (1920) 252 U.S. 60, 78, the court held unconstitutional a provision of the New York Income Tax Law which discriminated against nonresidents, saying: "Of course the terms 'resident' and 'citizen' are not synonymous, and in some cases the distinction is important (LaTourette v. McMaster, 248 U.S. 465, 470); but a general taxing scheme such as the one under consideration, if it discriminates against all non-residents, has the necessary effect of including in the discrimination those who are citizens of other States; and, if there be no reasonable ground for the diversity of treatment, it abridges the privileges and immunities to which such citizens are entitled." Cf. Blake v. McClung (1898) 172 U.S. 239.

51 LaTourette v. McMaster (1919) 248 U.S. 465 (sustaining a statute limiting the insurance business in the state to residents); $c f$. Maxwell v. Bugbee (1919) 250 U.S. 525 (a tax case).

52 (1929) 279 U.S. 377. The case is commented on in Notes (1930) 18 CaIrF. L. REv. 159; (1932) 30 MTCH. L. REv. 610; (1930) 39 YaLE L. J. 388 ; (1930) 24 Ir工. L. REv. 826.

53 N. Y. GeNerat CoRp. LAW (1943) § 225: "An action against a foreign corporation may be maintained by another foreign corporation, or by a non-resident, in one of the following cases only: ... (4) Where a foreign corporation is doing business within this state." The statute is held to give discretion to the courts to decline jurisdiction of cases brought under subdivision (4). Waisikoski v. Philadelphia \& Reading C. \& I. Co. (1916) 173 App. Div. 538, 159 N. Y. Supp. 906; Bagdon v. Philadelphia \& Reading C. \& I. Co. (1917) 178 App. Div. 662, 165 N. Y. Supp. 910. 
missed the action, and this was affirmed by the New York Court of Appeals. In upholding the validity of the statute, Justice Holmes delivering the opinion of the Court said:

"But however often the word resident may have been used as equivalent to citizen, and for whatever purposes residence may have been assumed to follow citizenship, there is nothing to prohibit the legislature from using 'resident' in the strict primary sense of one actually living in the place for the time, irrespective even of domicile." $5 t$

After referring to New York decisions upholding such a construction of the statute, he concluded that under the statute:

"There is no discrimination between citizens as such, and none between non-residents with regard to these foreign causes of action. A distmction of privileges according to residence may be based upon rational considerations and has been upheld by this Court, emphasizing the difference between citizenship and residence. ${ }^{.5} \ldots$ There are manifest reasons for preferring residents in access to often overcrowded Courts, both in convemience and in the fact that broadly speakmg it is they who pay for maintaining the Courts concerned."

As pointed out by commentators, ${ }^{57}$ a much inore satisfactory interpretation of the Douglas and similar cases would be that the privileges and immunities clause is not only limited to the protection of those privileges and immunities which are "in their nature fundamental" but even as to such fundamental privileges only unreasonable discriminations are forbidden. ${ }^{58}$ But whatever the theory, ${ }^{60}$ the Doug-

54279 U. S. at 386.

55 Here Justice Holmes cited LaTourette v. McMaster and Maxwell v. Bugbee, both supra note 51. He said that the decision in Blake v. McClung, supra note 50, was modified by the later decision in the LaTourette case, but did not mention Travis v. Yale \& Towne Mfg. Co., supra note 50.

56279 U.S. at 387.

57 Notes (1930) 18 CarTr. L. Rev. 159; (1932) 30 MTCH. L. Rev. 610.

58 "The results may then be summarized somewhat as follows: Rights guaranteed under Article IV, Section 2 are not protected absolutely, but only to the extent that a state cannot unreasonably, nor arbitrarily discriminate against non-citizens or non-residents; and the distinction between resident and citizen is valuable only as a factor entering into the determination of the reasonableness of the legislation and not as an independent element withdrawing the legislation from the provisions of Article IV, Section 2." Note (1930) 18 CaIIF. L. REv. 159, 163. Cf. Canadian Northern Ry. Co. v. Eggen, stupra note 45; Duehay v. Acacia Mut. Life Ins. Co. (App. D. C. 1939) 105 F. (2d) 768, 124 A. L. R. 1268.

59 As recently as 1942, the Supreme Court has said that the Douglas case sustained the state statute involved "because it treated citizens and noncitizens alike and tested their right to maintain an action by their residence or nonresidence". Miles $v$. Illinois Central R. Co., supra note 11, at 704, n. However, only four justices appear to have concurred in this portion of the opinion. 
las case has recently been cited with evident approval ${ }^{60}$ and the validity of a reasonable state statute vesting discretion in its courts to refuse to hear suits between nonresidents-as distinguished from noncitizens-seems clear.

What then of the constitutional validity of a state court applying a nonstatutory rule of forum non conveniens to dismiss a suit brought by a nonresident? If the court should dismiss a suit solely because the plaintiff was a citizen of another state, the validity of its action would seem open to serious question. If the suit should be dismissed because the plaintiff was not a resident "in the strict primary sense of one actually living in the place for the time, irrespective even of domicile", the validity of its action would appear to be settled by the Douglas case. What would be the result, however, if the court excluded a nonresident plaintiff in the application of the broad doctrine of forum non conveniens under which any plaintiff, resident or nonresident, citizen or noncitizen, may be denied the right to brimg his suit when the ends of justice would be better served by trial in another court? Clearly, here no substantial question as to the constitutional validity of the court's action would appear since the application of the doctrine would depend on other factors than the mere residence or citizenship of the parties.

The decision in the Douglas case, however, has not resulted in any widespread movement by the states to adopt the doctrine of forum non conveniens. In fact, not even the states which based their rejection of the doctrine on Article IV, Section 2, have been affected. In Minnesota ${ }^{61}$ and Missouri ${ }^{62}$ the courts dismissed the Douglas case by saying that in any event the statutes of the state deprived the courts of discretion to refuse jurisdiction. In Wisconsin ${ }^{63}$ the courts have continued to rely on the privileges and immunities clause, completely ignoring the Douglas case. ${ }^{64}$

00 Gulf Oil Corp. v. Gilbert, supra note 6, at 504. See also dissenting opinion of Justice Reed in Koster v. Lumbermens Mutual Co., supra note 42, at 534; Jackson, Full Faith and Credit-The Lawyer's Clause of the Constitution (1945) 45 Cor. L. Rev. 1, 31.

61 Boright v. Chicago, R.I. \& P. R. Co.; Hoch v. Byram, both supra note 13.

62 Bright v. Wheelock, supra note 40 .

03 State ex rel. Smith v. Belden (1931) 205 Wis. 158, 236 N.W. 542; Sheehan v. Lewis (1935) 218 Wis. 588,260 N. W. 633 ; Bourestom v. Bourestom supra note 40 . See also Fine v. Wencke, supra note 40.

64 In addition to the possible bar of the privileges and immunities clause, the doctrine of forum non conveniens might have been largely excluded from application to suits based on causes of action arising in other states of the Umited States if the full faith and credit clause (U.S. CoNsT., ART. IV, $\S 1$ ) had been construed as applying. But in the early case of Anglo-American Prov. Co. v. Davis Prov. Co. (1903) 191 U.S. 373, the 


\section{B. Federal Courts.}

Development of the doctrine of forum non conveniens in the federal courts has been impeded by the oft-expressed assertion that a federal court having jurisdiction of the parties and the subject matter of the action is under a duty to exercise that jurisdiction. In a number of early cases in which dismissal of the action in the federal court was sought because an action was pending between the same parties for the same cause in a state court or the state statutes provided for an exclusive remedy in the state courts, the United States Supreme Court upheld the jurisdiction of the federal courts, making broad statements to the effect that a federal court having jurisdiction is under a duty to exercise it. ${ }^{65}$ And a dictum in the Second Employers' Liability Cases ${ }^{06}$ to the effect that the "existence of the jurisdiction creates an implication of duty to exercise it, and that its exercise may be onerous does not militate against that implication" was relied upon in a number of lower federal court cases to support their refusal to apply forum non conveniens in Federal Employers' Liability Act cases. ${ }^{67}$

United States Supreme Court held that the New York statute which then denied jurisdiction to the courts of the state in suits by nonresidents against foreign corporations did not violate the full faith and credit clause when applied to deny jurisdiction of a suit between two foreign corporations on an Illinois judgment. Recently the Court has said by way of dictum that under the clause a state "may in appropriate cases apply the doctrine of forum non conveniens". Broderick v. Rosner (1935) 294 U.S. 629, 643; see also Williams v. North Carobina (1942) 317 U.S. 287, 294, n.; Gulf Oil Corp. v. Gilbert, supra note 6 , at 504. These cases leave little doubt that the full faith and credit clause does not prevent application of the doctrine of forun non conveniens. See Jackson, loc. cit. supra note 60 .

65 Cases where state statutes attempted to restrict remedies to state courts: Suydam v. Broadnax (1840) 39 U. S. (14 Pet.) 66; The Union Bank of Tennessee v. Jolly's Adm'rs (1855) 59 U.S. (18 How.) 503; Hyde v. Stone (1857) 61 U.S. (20 How.) 170, 175 ("But the courts of the United States are hound to proceed to judgment, and to afford redress to suitors before them, in every case to which their jurisdiction extends. They cannot abdicate their authority or duty in any case in favor of another jurisdiction."); Chicot County v. Sherwood (1893) 148 U.S. 529, 534. Case where another action was pending in a state court: McClellan v. Carland (1910) 217 U.S. 268, 282. See also Cohens v. Virginia (1821) 19 U.S. (6 Wheat.) 264, 404; Denick v. Railroad Co. (1880) 103 U.S. 11, 18; Willcox v. Consolidated Gas Co. (1909) 212 U.S. 19, 40; Southern California Tel. Co. v. Hopkins (C. C.A. 9th, 1926) 13 F. (2d) 814, 820, af'd., Hopkins v. Southern California Tel. Co. (1928) 275 U.S. 393.

66 (1912) 223 U.S. 1, 58. This statement was directed to the holding of the case, i.e., state courts could not refuse to hear cases brougbt under the F.E. L.A. because of local policy or because of the inconvenience of applying different standards to the employers' liability in cases arising under the federal and state statutes.

6r' Schendel v. MeGee (C. C. A. 8th, 1924) 300 Fed. 273 ; Southern Ry. Co. v. Cochran (C. C. A. 6th, 1932) 56 F. (2d) 1019; Norris v. Illinois Cent. R. Co. (D. Minn. 1925) 18 F. (2d) 584; cf. Smith v. Empire State-Idaho M. \& D. Co. (C.C. E.D. Wash. 1904) 127 Fed. $462,465$. 
In other types of cases, however, it was recognized that the grant of power to the federal courts does not imply an absolute duty to exercise that power. ${ }^{68}$ At an early date it was held that the federal courts had discretion to refuse to hear suits in admiralty brought between aliens. ${ }^{69}$ An examination of these cases caused the Court to say in Canada Malting Co. v. Paterson Co.: ${ }^{\mathrm{T} 0}$
"Obviously, the proposition that a court having jurisdiction must exercise it, is not umversally true; else the admiralty court could never decline jurisdiction on the ground that the litigation is between foreigners. Nor is it true of courts administering other systems of our law. Courts of equity and of law also occasionally decline, in the in- terest of justice, to exercise jurisdiction, where the suit is between aliens or non-residents or where for kindred reasons the litigation can more appropriately be conducted in a foreign tribunal."

Shortly after the Canada Malting Co. case the Supreme Court in Rogers v. Guaranty Trust Co ${ }^{71}$ recognized discretion in the federal courts to decline jurisdiction in another class of cases-those where the internal affairs of foreign corporations were involved: ${ }^{72}$

\begin{abstract}
"While the district court had jurisdiction to adjudge the rights of the parties, it does not follow that it was bound to exert that power... . It was free in the exercise of a sound discretion to decline to pass upon the merits of the controversy and to relegate plaintiff to an appropriate forum. ... But it safely may be said that jurisdiction will be declined whenever considerations of convenience, efficiency and justice point to the courts of the State of the domicile as appropriate tribunals for the determination of the particular case."T3
\end{abstract}

More recently the Supreme Court in Burford v. Sun Oil Co. ${ }^{74}$ extended the list of exceptional situations ${ }^{\text {T̃ }}$ where the federal courts

es See generally American Automobile Ins. Co. v. Freundt (C. C. A. 7th, 1939) 103 F. (2d) 613 .

69 The Belgenland, supra note 36; Charter Shipping Co. v. Bowring, etc. (1930) 281 U. S. 515; see Coffey, loc. cit. supra note 36.

70 (1932) 285 U. S. 413, 422; cf. Langnes v. Green (1931) 282 U.S. 531, 541.

71 (1933) 288 U.S. 123.

72 The rule had previously become general in state cases that whenever the internal affairs of a foreign corporation were involved in a suit, jurisdiction would be declined. See generally Fletcrer, Cyctopedia of Corporations (Perm. ed. 1933) \$\$ 8425-8445; Restatearent, Conflict of Laws (1934) §§ 192-202; Note (1933) 33 Cot. L. Rev. 492. The development of the rule in the federal courts is traced in detail in Note (1946) 46 Cor. L. REv. 413.

73288 U.S. at $130,131$.

74 (1943) 319 U.S. 315.

75 E.g., cases holding that federal courts may decline to interfere (1) with state criminal prosecutions: Spielman Motor Co. v. Dodge (1935) 295 U. S. 89; Beal v. Mis- 
could refuse to exercise their equity jurisdiction. The Court held that jurisdiction could be refused in a diversity case on essentially forum non conveniens grounds, i.e., when a decision by the federal court would interfere with a state administrative system for regulating the oil industry. ${ }^{76}$

The decisions in Meredith v. Winter Haven ${ }^{7 \pi}$ and Williams $v$. Green Bay \& W.R. Co. ${ }^{78}$ however, cast doubt upon the general availability of the doctrine of forum non conveniens in the federal courts. The Meredith case limited the Burford case to its facts and expressed the policy that a federal court with jurisdiction in a diversity case must exercise that jurisdiction, with the narrow exception of situations where a federal equity court in the exercise of its equity jurisdiction might refuse to grant an equitable remedy.

"The diversity jurisdiction was not conferred for the benefit of the federal courts or to serve their convenience. Its purpose was generally to afford to suitors an opportunity in such cases, at their option, to assert their rights in the federal rather than in the state courts." ${ }^{9}$

In the Williams case the court limited the application of Rogers $v$. Guaranty Trust $C 0 .{ }^{80}$ holding that the mere fact that internal affairs of a foreign corporation are involved is not enough to justify the federal courts in refusing jurisdiction. However, by dictum the Court

souri Pacific R. Co (1941) 312 U.S. 45; Douglas v. Jeannette (1943) 319 U.S. 157; (2) with collection of state taxes or with fiscal affairs of the state: Matthews v. Rodgers (1932) 284 U. S. 521 ; Stratton v. St. L. S. W. Ry. (1932) 284 U. S. 530; Great Lakes Co. v. Huffman (1943) 319 U.S. 293 ; (3) with the state administrative function of prescribing the local rates of public utilities: Central Kentucky Co. v. Railroad Comm. of Ky. (1933) 290 U.S. 264; (4) with the liquidation of an insolvent state bank by a state administrative officer: Pennsylvania v. Williams (1935) 294 U.S. 176; Gordon v. Washington (1935) 295 U.S. 30; Kelleam v. Maryland Casualty Co. (1941) 312 U.S. 377. See also Di Giovanni v. Camden Ins. Ass'n (1935) 296 U.S. 64; Thompson v. Magnolia Petroleum Co. (1940) 309 U.S. 478; Railroad Comm. v. Pullman Co. (1941) 312 U.S. 496; Chicago v. Fieldcrest Dairies (1942) 316 U.S. 168. The cases are discussed in Notes (1944) 53 Yare L. J. 788; (1943) 56 HaRv. L. Rev. 1162; (1944) 18 TULANe L. Rev. 492. ${ }^{76}$ See also Railroad Comm. v. Oil Co. (1940) 310 U.S. 573.

75 (1943) 320 U.S. 228. This was a diversity case in which plaintiffs sought declaratory relief as to the extent of liability of a Florida municipality upon its refunding bonds. The circuit court of appeals held that in view of the conflict and uncertainty among the Florida courts as to the applicable state law and the fact that no federal question was involved, the federal court should refuse jurisdiction. The Supreme Court reversed, holding that mere difficulty of ascertaining state law was not a sufficient basis for refusing to exercise diversity jurisdiction.

78 (1946) 326 U.S. 549.

79 320 U.S. at 234.

80 Supra note 71 . 
asserted that the doctrine of forum non conveniens might apply to permit a federal court to decline an internal affairs case where the suit would be vexatious or oppressive, or where the relief sought might be so extensive or call for such detailed and continuing supervision that the matter could be better handled nearer home. ${ }^{81}$

The question of the power of federal courts to apply forum non conveniens was settled only this past term in the cases of Koster $v$. Lumbermens Mutual Co. ${ }^{82}$ and Gulf Oil Corp. v. Gilbert. ${ }^{83}$ The Koster case was a derivative action brought in the federal district court for the Eastern District of New York by a New York policyholder against an Illinois insurance company and other Illinois defendants. The district court found that an unnecessary burden would be placed on the defendants by trial in New York where none of the witnesses nor the records were available and that the suit mvolved the internal affairs of a foreign corporation. A motion to dismiss under the doctrine of forum non conveniens was granted and the second circuit court of appeals affirmed. The Supreme Court in a 5-to-4 decision held that since the defendant had shown much harassment and the plaintiff had shown little countervailing benefit to himself in the choice of forum, the judgment should be affirmed. ${ }^{84}$ The Court added, however, that the mere fact that internal affairs of a foreign corporation were involved would not be enough to justify the dismissal.

"That is one, but only one, factor which may show convenience of parties or witnesses, the appropriateness of trial in a forum familiar with the law of the corporation's domicile, and the enforceability of the remedy if one be granted. But the ultimate inquiry is where trial will best serve the convenience of the parties and the ends of justice." 85

The Gilbert case was the first suit at law for money damages to come before the Supreme Court in which forum non conveniens was invoked as a defense. A Virginia resident brought a suit for damages in the United States District Court for the Southern District of New York against a Pennsylvania corporation, alleging that the plaintiff's warehouse in Virginia had burned as the result of defendant's negligence in delivering gasoline to the warehouse tanks and pumps. Juris-

81326 U.S. at 554. See Note (1946) 46 CoL. L. Rev. 413.

82 Supra note 42.

83 Supra note 6.

84 The dissenting justices did not question the general validity of the defense of fortm non conveniens but argued that in this case the defendant had not made a sufficient sbowing to justify its application.

85330 U.S. at 527. 
diction was based solely on diversity of citizenship. The district court dismissed under the doctrine of forum non conveniens. The second circuit court of appeals reversed. The Supreme Court in another 5-to-4 decision held the doctrine applicable and reversed the judgment of the circuit court of appeals. ${ }^{80}$ The mere fact that under the venue statutes the district court had power to hear the case did not control. "This Court, in one form of words or another, has repeatedly recognized the existence of the power to decline jurisdiction in exceptional circumstances. ${ }^{387}$ The Court reviewed the earlier cases in which it had referred to the doctrine, dismissed Meredith $v$. Winter Haven ${ }^{88}$ with a "but cf.", and concluded, by way of a footnote, that the application of the doctrine does not depend on whether the action is at law or in equity. The Court then discussed the scope of the doctrine"The principle of forum non conveniens is simply that a court may resist imposition upon its jurisdiction even when jurisdiction is authorized by the letter of a general venue statute"80 - and the facts of this case, concluding that it was one "of those rather rare cases where the doctrine should be applied". ${ }^{00}$ Justice Black, dissenting, argued that the decision of the Court amounted to an amendment to the venue statutes.

"No such discretionary authority to decline to decide a case, however, has, before today, been vested in federal courts in actions for money judgments deriving from statutes or the common law. To engraft the doctrine of forum non conveniens upon the statutes fixing jurisdiction and proper venue in the district courts in such actions, seems to me to be far more than the mere filling in of the interstices of those statutes.... Whether the doctrine of fornm non conveniens is good or bad, I should wait for Congress to adopt it." ${ }^{01}$

One question left open is whether the state law as to forum non conveniens must control in diversity cases under Erie R. Co.v. Tomp-

86 Justices Black and Rutledge argued that federal courts had no authority to apply forum non conveniens in a law case. Justices Reed and Burton, by adopting their dissent in the Koster case, apparently agreed that the doctrine could apply but felt that here again the defendant had not made a sufficient showing to justify its application.

87330 U.S. at 504.

88 Supra note 77.

89330 U.S. at 507.

90 Ibid. at 509. The Court rejected plaintiff's argument that the damages claimed $(\$ 400,000)$ were so large as to "stagger" the imagination of a local Virginia jury: ". . we cannot say the District Court was bound to entertain a proviucial fear of the provincials ism of a Virginia jury. That leaves the Virginia plaintiff without even a suggested reason for transporting this suit to New York" Ibid. at 510.

01 Ibid. at 515, 517 . 
kins. ${ }^{92}$ The second circuit court of appeals has held both ways on this question $^{83}$ and in the Williams, ${ }^{94}$ Koster $^{95}$ and Gilbert ${ }^{96}$ cases the Supreme Court expressly refused to decide the question, assuming in each case that the same result would have been reached if the state law were applied. It has been argued that forum non conveniens is essentially a jurisdictional question which must be decided by the federal courts without regard to state rules on the subject. ${ }^{9 \pi}$ That the Supreme Court may eventually so hold is at least suggested by its assertion, in another connection, in the Koster case that we "are concerned here with the autonomous administration of the federal courts in the discharge of their own judicial duties". 98

\section{Federal Employers' Liability Act Cases.}

The doctrine of forum non conveniens can be most useful in suits against railroads under the Federal Employers' Liability Act where the most flagrant examples of abuse of the venue privilege are found. But the United States Supreme Court has raised considerable doubt as to the availability of the doctrine in such cases in either the state or federal courts. The matter was thought to be settled in favor of the applicability of the doctrine by the holding in Douglas $v$. New Haven R. $\mathrm{Co}^{99}$

“[The Federal Employers' Liability Act] does not purport to require State Courts to entertain suits arising under it, but only to empower them to do so, so far as the authority of the United States is concerned. It may very well be that if the Supreme Court of New York were given

92 (1938) 304 U.S. at 64.

93 Holding that the state law controls: Weiss v. Routh (C. C. A. 2 d, 1945) 149 F. (2d) 193. Holding that the state law does not control: Gilbert v. Gulf Oil Corporation (C. C. A. 2d, 1946) 153 F. (2d) 883, rev'd, (1947) 330 U.S. 501 ; Koster v. Lumbermen's Mutual Co. (C. C. A. 2d, 1946) 153 F. (2d) 888, aff'd, (1947) 330 U. S. 518.

94326 U.S. at 558.

95330 U.S. at 529 .

90330 U.S. at 509.

07 (1946) 14 U. of CEI. L. Rev. 97. See also Koster v. Lumbermens Mutual Co., supra note 93. Cf. Note (1946) 46 Cox. L. REv, $413,425$.

98330 U. S. at $520, \mathrm{n}$. The Court made this statement in distinguishing cases such as those cited in note 65, supra, in which it had been held that a federal court with jurisdiction must exercise it.

89279 U. S. at 387 ; cf. Second Employers' Liability Cases, supra note 66, at 56. The ruling of the Douglas case was approved by dictum in McKnett v. St. Louis \& S. F. Ry. Co., supra note 45, at 233: "While Congress has not attempted to compel states to provide courts for the enforcement of the Federal Employers' Liability Act, Douglas v. New York, N. H. \& H. R. Co. . . the Federal Constitution prohibits state courts of general jurisdiction from refusing to do so solely because the suit is brought under a federal law." 
no discretion, being otherwise competent, it would be subject to a duty. But there is nothing in the Act of Congress that purports to force a duty upon such Courts as against an otherwise valid excuse."

However, some question as to the present scope of this ruling is raised by recent cases holding that state courts have no power to enjoin prosecution of actions under the F.E.L. A. ${ }^{100}$ In Baltimore \& Ohio $R$. Co. v. Kepner, ${ }^{101}$ an injunction was sought in an Ohio court against the prosecution by an Ohio resident of an action under the F.E. L. A. in the federal district court in New York. The injuries which were the basis of the suit were received in Ohio, and the petitioner argued that a heavy burden would be cast upon it by defending the suit in New York in view of the many witnesses who would have to be transported there. The Ohio courts held that the venue provisions of the F.E. L. A. deprived them of power to enjoin prosecution of the suit. The Supreme Court affirmed, holding that the federal statute conferred upon the injured employee the privilege of bringing suit wherever the railroad was doing business and that under the supremacy clause "no state court may interfere with the privilege, for the benefit of the carrier or the national transportation system, on the ground of inequity based on cost, inconvenience or harassment. . . . A privilege of venue, granted by the legislative body which created this right of action, cannot be frustrated for reasons of convenience or expense." ${ }^{102}$ The Court made no reference to the Douglas case nor to the possibility of applying the doctrine of forum non conveniens in the forum state. In Miles v. Illinois Central R. Co., ${ }^{103}$ the Tennessee courts, under circumstances similar to those in the Kepner case, issued an injunction against prosecuting an action under the F. E. L. A. in the state courts of Missouri. The Court held this action invalid on the authority of the Kepner case and said by way of dictum that the Missouri courts would be required to hear the suit under the privileges and immunities clause. The Court distinguished the Douglas case, ${ }^{104}$ and then said:

"This is not to say that states cannot control their courts. We do not deal here with the power of Missouri by judicial decision or legislative

100 Prior to these decisions the state courts frequently granted injunctions in F. E.

L. A. cases. See authorities in notes 18 and 21, supra.

101 Supra note 11. See law review articles in note 21, supra; Note (1942) 14 RockY

MT. L. Rev. 126; (1942) 16 Tutane L. Rev. 290; (1942) 90 U. of PA. L. Rev. 489.

102314 U. S. at 53,54 .

103 Supra note 11.

104 Supra note 59. 
enactment to regulate the use of its courts generally, as was approved in the Douglas [case].... We are considering another state's power to so control its own citizens that they cannot exercise the federal privilege of litigating a federal right in the court of another state."105

In a concurring opinion, Justice Jackson said that he did not agree with the dictum that the Missouri courts must hear the case. Four justices dissented.

In Leet v. Union Pac. R. R. Co., ${ }^{106}$ the California supreme court read the Miles and $K e p n e r$ cases as deciding that the venue privilege conferred by the F.E.L.A. is absolute and cannot be defeated on the ground of forum non conveniens. The United States Supreme Court denied certiorari. ${ }^{107}$ In Herb v. Pitcairn, ${ }^{108}$ the Supreme Court of the United States quoted with approval, in another connection, the quotation from the Douglas case set out above. But in Gulf Oil Corp. v. Gilbert that Court appears to approve by dictum the position taken by the California court in the Leet case:

"It is true that in cases under the Federal Employers" Liability Act ... we have held that plaintiff's choice of a forum cannot be defeated on the basis of forum non conveniens. But this was because the special venue act under which those cases are brought was believed to require it." 109

The Court cited the Kepner and Miles cases as authority for this statement. In those cases, however, the Court was not required to decide the question of the availability of the plea of forum non conveniens in the forum court since the action in each was for an injunction against suit in another jurisdiction. The two situations present different considerations and it is hoped that when the issue is squarely presented the Court will hold that the plea of forum non conveniens is available

105315 U.S. at 704.

108 Supra note 41; (1945) 58 Harv. L. Rev. 877; (1945) 18 So. CarTe. L. Rev. 281. Plaintiff was appointed administratrix of the estates of Thatcher and Utterback who were killed in Portland, Oregon, while in the employ of the defendant railroad. Plaintiff brought suit for wrongful death in the Superior Court in Los Angeles county. The railroad brought suit in an Oregon court to enjoin the heirs of the decedents from prosecuting the California action. The Supreme Court of Oregon reversed the decrees of the Oregon trial court granting the injunctions. Union Pac. R. Co. v. Utterback, supra note 9. The United States Supreme Court denied certiorari. (1944) 323 U. S. 711. Meanwhile the California court had refused to decline jurisdiction of the case and this action was affirmed in the Leet case.

107 (1945) 325 U.S. 866.

108 (1944) 324 U.S. 117, 120.

109330 U. S. at 505. 
to assist in curbing the abuses which have arisen in suits under the F. E. L. A. ${ }^{110}$

\section{PRACTICAL OPERATION OF THE DOCTRINE OF Forum Non Conveniens.}

Our survey thus far has shown that with the possible exception of cases arising under the Federal Employers' Liability Act there are no federal constitutional or statutory provisions preventing the widespread application of the doctrine of forum non conveniens in both state and federal courts. It is not enough, however, to argue that trial courts should have discretion to refuse to hear cases under the doctrine. Meaming must be given to the phrase. Trial judges must know what factors they are to consider when deciding whether to exercise their discretion. ${ }^{111}$ More important, litigants must have some basis for forecasting a court's ruling on assumption of jurisdiction if unnecessary expense and wasted time are to be avoided. ${ }^{112}$ And here appellate courts have not, in fact, left the trial courts with untrammelled discretion. ${ }^{113}$ They either have substituted their own discretion for that of the trial court, ${ }^{114}$ or have limited the scope of the trial

110 The fundamental solution, of course, lies in removing the necessity for such suits by adopting an adequate workmen's compensation system to cover employees of interstate railroads. See Winters, op. cit. supra note 14, at 144.

111 Bowers, Judictal Discretion of Trial Courts (1931) § 10.

112 Justice Black, dissenting in Gulf Oil Corp. v. Gilbert, supra note 6, at 516, argued that the doctrine of forum non conveniens should not be extended to law cases in the federal courts because of the uncertainty produced. "The broad and indefinite discretion left to federal courts to decide the question of convenience from the welter of factors which are relevant to such a judgment, will inevitably produce a complex of close and indistinguishable decisions from which accurate prediction of the proper forum will becoine difficult, if not impossible." However, in most cases where the plaintiff has the choice of several forums in which to sue, there will be no doubt of his right to bring suit in most of them. Only when he seeks to sue in the more unlikely forums must he weigh the disadvantages of uncertainty against the advantages he seeks in the forum. See Dainow, op. cit. supra note 24, at 888 . And if the factors governing the exercise of discretion are more closely defined as additional cases come before the appellate courts, this uncertainty will be reduced.

${ }^{113}$ See Weiss v. Routh, supra note 93, at 195: "Here, as elsewhere, although judicial discretion does indeed imply that the limits are not rigidly fixed, it does not mean that there are none ..." Cf. Langnes v. Green, supra note 70, at 541: "When invoked as a guide to judicial action it [the term 'discretion'] means a sound discretion, that is to say, a discretion exercised not arbitrarily or wilfully, but with regard to what is right and equitable under the circumstances and the law, and directed by the reason and conscience of the judge to a just result." See also Universal Adjustment Corp. v. Midland Bank, supra note 41.

114 Hoes v. New York, N. H. \& H. R. R. Co., supra note 48; Collard v. Beach, sicpra note 37; Jackson \& Sons v. Lumbermens Mutual Co., stupra note 41. In Williams v. 
court's discretion. ${ }^{115}$ Of major importance, then, is an examination of the guideposts which have been erected for the exercise of the trial court's discretion.

At the outset we can put aside those cases, now thought of as $a_{i}$ part of the doctrine, where the court refuses to hear a suit because of its inability to give effective relief. ${ }^{116}$ Where the procedural law of the forum affords no remedy comparable to that provided in the jurisdiction creating the right of action, ${ }^{117}$ where the relief demanded would involve detailed and continuous supervision of activities in another jurisdiction, ${ }^{118}$ or where for other reasons the court cannot make its decision effective, courts have always refused jurisdiction. ${ }^{119}$ These are rare cases, arising most often when the internal affairs of foreign corporations are involved, and the special difficulties presented by such cases have been fully discussed elsewhere. ${ }^{120}$

Our main consideration here will be to examine those rules which govern the trial court in the exercise of its discretion when no doubt is raised as to the effectiveness of the court's decree. The cases will be reviewed in an attempt to determine (a) who is to be benefited by application of the doctrine of forum non conveniens and the effect of the answer to this question on (b) the factors which will justify the exercise of discretion to decline jurisdiction, and (c) the procedural rules goverming application of the doctrine.

Green Bay \& W. R. Co., supra note 78, the United States Supreme Court appeared to give little or no scope to the discretion of the trial court in reversing its decision to assume jurisdiction. See (1946) 59 Harv. L. Rev. 621. But cf. Koster v. Lumbermens Mutual Co., supra note 42 , and the discussion infra.

115 The conventional statement is that the assumption of jurisdiction is ordinarily within the sound judicial discretion of the trial court and that its ruling will not be disturbed on appeal unless an abuse of that discretion can be shown. Canada Malting Co. v. Paterson Co., supra note 70; The Kanto Maru (C. C. A. 9th, 1940) 112 F. (2d) 564; Universal Adjustment Corp. v. Midland Bank; Murnan v. Wabash Railway Co.; Horner v. Pleasant Creek Mining Corp., all supra note 41 ; State v. Fowler, supra note 46. What the courts actually do in these cases, however, is best summarized by Bowers, op. cit. supra note 111, at 86: "It is manifest here, however, that, as im most other phases of law involving judicial discretion, the trial court's ruling will be declared conclusive when, and when only, it accords with the views of the appellate tribunal as to what ought to have been done in the particular case." Cf. 1 WiGMoRE, EvIDENCE (3rd ed. 1940) 312.

116 See generally Williams v. Green Bay \& W. R. Co., supra note 78, at 555.

11 S Slater v. Mexican National R. R. Co. (1904) 194 U. S. 120; RestatedneNT, CoNFLICT OF LAws (1931) $\$ 808,609$.

118 Rothstein v. Rothstem (1947) 272 App. Div. 26, 68 N. Y. S. (2d) 305.

110 See Clark, Equity (1919) § 14; Note (1946) 46 CoL. L. REv. 413, 416, n.

120 Authorities cited in note 72, supra. 


\section{A. Who Is To Be Benefited by the Doctrine.}

The general inference to be drawn from the Latin phrase is that jurisdiction should be declined when the forum is inconvenient. But inconvenient to whom? The court? The plaintiff? The defendant? Even if we have an answer to these questions, is it enough that the scale is weighted more heavily on the side of inconvenience to the defendant when the plaintiff has acted in good faith? In other words, must there be an element of abuse of court process before jurisdiction is declined? Perhaps, the search should be a broader one for that forum in which the ends of justice will best be served. Obviously, these questions must be answered before we know anything of the meaning of the doctrine of forum non conveniens.

As the doctrine has developed in American courts emphasis has been placed primarily on inconvenience to the court as the principal reason for refusing jurisdiction. As early as 1848 a federal court in declining to hear an admiralty suit between British subjects said: "... it would be lamentable if courts were compelled to defer the business of the citizens of the country to bestow their time on litigations between parties owing no allegiance to its laws, and contributing in no way to its support." 121 In New York, where the doctrine of forum non conveniens has had its fullest development, the principal reason given for declining jurisdiction has been avoidance of the burden on the local courts and taxpayers. Thus in 1890 in Ferguson $v$. Neilson the court was able to say: ${ }^{122}$

"It is the well-settled rule of this state that, unless special reasons are shown to exist which make it necessary or proper to do so, the courts will not retain jurisdiction of and determine actions between parties residing in another state for personal injuries received in that state. ... The reason of the rule is obvious,--because the courts of this state should not be vexed with litigations between non-residents over causes of action arising outside of our own territorial limits. Our courts are not supported by the people for any such purpose."

In 1903 the New York Court of Appeals reversed the action of a trial court in assuming jurisdiction of a suit for the wrongful death in Con-

121 One Hundred \& Ninety-Four Shawls, supra note 36, at 705. Accord: Atchison, T. \& S. F. Ry. Co. v. Weeks (C. C. A. 5th, 1918) 254 Fed. 513; Heine v. New York Life Ins. Co., supra note 9; Goldinan v. Furness, Withy \& Co. (S. D. N. Y. 1900) 101 Fed. 467.

122 Supra note 37, at 504. This suit was an action for damages for personal injuries sustained in Rhode Island. Both parties were Rhode Island residents. See also Robinson v. Oceanic Steain Nav. Co., supra note 28; Dewitt v. Buchanan (1868) 54 Barb. 31. 
necticut of a Connecticut resident which was brought by a local administrator whose appointment had been fraudulently obtained, and said:

"If this can be done, it will open wide the floodgates of litigation in similar cases, establish a new legal industry, and impose thereby upon our already overworked courts the obligation to try actions imported from a foreign jurisdiction." 123

The emphasis of the New York courts on local interests as the basis for the doctrine is made even clearer by the limitation of the doctrine in that state to tort actions. In contract actions and other actions of a commercial character, where presumably some benefit will ultimately accrue to the state through encouraging the use of its courts in the furtherance of business activities, ${ }^{124}$ the trial court has no discretion to refuse jurisdiction. ${ }^{125}$ This rule is applied even though the parties are nonresidents or aliens and the defendant is able to show serious inconvenience or hardship if he is called upon to defend in New York. ${ }^{126}$ This emphasis in New York on inconvenience to the court

123 Hoes v. New York, N.H.\&H.R. R. Co., supra note 48. For other cases in which the New York courts have strongly emphasized the local burden, see Collard v. Beach, supra note 37; Gainer v. Donner (1931) 140 Misc. 841, 251 N. Y. Supp. 713 ; Reep v. Butcher (1941) 176 Misc. 369,27 N. Y.S. (2d) 330.

124 In the leading case of Werthein v. Clergue (1900) 53 App. Div. 122, 125, 65 N. Y. Supp. 750, 753, the court reversed the trial court's decision refusing to take jurisdiction of an action by a Gernan resident against a Maine resident for deceit based on false representations inducing the plaintiff to enter into a contract. The court recognized the general rule apphicable to tort cases and then said: "But we know of no reason founded in public policy, and certainly nothing resting in precedent, which will close the courts of this State to non-resident suitors who invoke their aid against other non-residents sojourning within our borders for the enforcement of causes of action arising out of commercial transactions and affecting property or property rights. No such narrow or illiberal policy has yet been declared by our courts. ... [We] certainly do not intend to establish a precedent which would shut our courts to great numbers of foreign merchants, non-residents of the State, who may find their non-resident debtors, fraudulent or honest, temporarily within our jurisdiction ...."

125 Wedemann v. United States Trust Co. (1932) 258 N.Y. 315, 179 N.E. 712; Rodger v. Bliss (1927) 130 Misc. 168, 223 N. Y. Supp. 401; Osborne v. Banco AlemanAntioqueno (1941) 176 Misc. 664, 29 N.Y.S. (2d) 236; Rederiet Ocean Aktieselskab v. W. A. Kirk \& Co. (N. Y. Sup. Ct. 1944) 51 N. Y. S. (2d) 565 ; cf. Rothstein v. Rothstein, supra note 118.

120 In an action by a resident of Mexico against a corporation doing business in Mexico on a contract entered into and to be performed in Mexico the court refused to dismiss despite a showing that all the witnesses, data and correspondence needed on the trial of the action were in Mexico. McMahon v. National City Bank of New York (1931) 142 Misc. 268, 254 N. Y. Supp. 279. Accord: Crane, Hayes \& Co. v. New York, N. H. \& H. R. R. Co. (1927) 131 Misc. 71, 225 N. X. Supp. 775; cf. Holzer v. Deutsche ReichbahnGesellschaft (1938) 277 N. Y. 474, 14 N. E. (2d) 798; Mandl v. Mandl (1946) 61 N. Y.S. (2d) 364. 
was reflected in the decisions in other states ${ }^{12 \pi}$ and approved by Blair, who suggested that a principal benefit to accrue from widespread application of the doctrine of forum non conveniens would be relief of "calendar congestion by partially diverting at its source the flood of litigation by which our courts are being overwhelmed". ${ }^{128}$

An entirely different conception of the doctrine of forum non conveniens is presented in the English and Scottish cases. In the Scottish cases inconvenience to the court is definitely rejected as a factor and it is said that the plea of forum non conveniens will be upheld only when it can be shown that the ends of justice will best be served by trial in another forum. The Scottish point of view is set forth in detail in La Société du Gaz de Paris v. La Société Anonyme de Navigation "Les Armateurs français." In that case a French inanufacturing firm sued French shipowners in a Scottish court (basing jurisdiction on the arrest of a vessel owned by the defendants and found in Scotland) for the breach of a contract on a charter party executed in France for delivery of goods from England to France. The ship sank. The plaintiffs contended that it was improperly loaded, that it was a ship of French design notoriously unseaworthy, and that the defendant had not taken steps recommended by the French authorities to make it seaworthy. The Scottish court dismissed on a plea of forum non conveniens and the House of Lords affirmed. Lord Chancellor Cave summarized the doctrine:

"... if in any case it appeared to the Court, after giving consideration to the interests of both parties and to the requirements of justice, that the case could not be suitably tried in the Court in which it was instituted, and full justice could not be done there to the parties, but could be done in another Court, then the former Court might give effect to the plea by declining jurisdiction and permitting the issues to be fought out in the more appropriate Court."130

Lord Dunedin said:

"... there is here another Court of competent jurisdiction in which the case may be tried more suitably for the interests of all the parties and for the ends of justice." 131

127 Jackson \& Sons v. Lumbermen's Mut. Casualty Co.; Grovey v. Washington Nat. Ins. Co., both supra note 41; Sielcken v. Sorenson (1932) 111 N. J. Eq. 44, 161 Atl. 47; Mexican Nat. R. Co. v. Jackson (1896) 89 Tex. 107, 33 S. W. 857.

128 Blair, loc. cit. supra note 33.

129 Suppra note 35. See also GIBB, loc. cit. supra note 35; Gloag and Henderson, loc. cit. supra note 35 .

130 [1926] Sess. Cas. (H. L.) at 16.

131 Ibid. at 18. 


\section{Lord Sumner said:}

"Obviously the Court cannot allege its own convenience, or the amount of its own business, or its distaste for trying actions which involve taking evidence in French, as a ground for refusal. ... The object under the words 'forum non conveniens' is to find that forum which is the more suitable for the ends of justice, and is preferable because pursuit of the litigation in that forum is more likely to secure those ends." 132

The English courts have a slightly narrower conception of the doctrine. They appear to limit it to cases "in which the Court should, in its discretion, exercise its inherent power to prevent its procedure from being abused for the purpose of oppression and with the result of working injustice". ${ }^{133}$ The emphasis is on abuse of the court's process and apparently both serious injustice to the defendant and an improper motive on the part of the plaintiff are necessary to call forth the application of the doctrine. Thus in Logan v. Bank of Scotland $d^{134}$ application was made to the court to stay all further proceedings in the action on the ground that it was vexatious and an abuse of process of the court. A showing was made that a serious burden was placed on defendant, and that the only reason for bringing the action in England was to coerce a settlement because the amount in suit was quite out of proportion to the cost of defending. In Egbert v. Short ${ }^{135}$ the court relied on the "inherent jurisdiction of the Court to prevent an abuse of its process". In In re Norton's Settlement, Williams, L. J., said:136

"In my opinion it must be proved to the satisfaction of the Court that either the expense or the difficulties of trial in this country are so great that injustice will be done-in this sense, that it will be very difficult, or practically impossible, for the litigant who is applying for the stay to get justice in this country."

And, Farwell, I. J., said:

"Now, abuse suggests to one's mind an element of wrong-doing in the party attempting so to abuse, and I think that $\mathrm{m}$ all the reported cases that element does appear. It is not necessary for us to determine whether the mere question of inconvemience would of itself be sufficient without that element."137

132 Ibid. at 21, 22.

${ }^{133}$ Kennedy, L. J., in In re Norton's Settlement, supra note 37, at 485.

134 Supra note 37.

135. Supra note 37, at 210.

130 [1908] 1 Ch. at 479.

137 Ibid. at 482. 
The tendency in recent American cases applying the doctrine of forum non conveniens has been to hold that both convenience to the parties and convenience to the court are to be considered. ${ }^{138}$ This approach is best illustrated by the statement of the United States Supreme Court in Gulf Oil Corp. v. Gilbert: $:^{139}$

"Wisely, it has not been attempted to catalogue the circumstances which will justify or require either grant or denial of remedy. The doctrine leaves much to the discretion of the court to which plaintiff resorts, and experience has not shown a judicial tendency to renounce one's own jurisdiction so strong as to result in many abuses.

"If the combination and weight of factors requisite to given results are difficult to forecast or state, those to be considered are not difficult to name. An interest to be considered, and the one likely to be most pressed, is the private interest of the litigant. Important considerations are the relative ease of access to sources of proof; availability of compulsory process for attendance of unwilling, and the cost of obtaining attendance of willing, witnesses; possibility of view of premises, if view would be appropriate to the action; and all other practical problems that make trial of a case easy, expeditious and inexpensive. There may also be questions as to the enforceability of a judgment if one is obtained. The court will weigh relative advantages and obstacles to fair trial. It is often said that the plaintiff may not, by choice of an inconvenient forum, 'vex,' 'harass,' or 'oppress' the defendant by inflicting upon lim expense or trouble not necessary to his own right to pursue his remedy. But unless the balance is strongly in favor of the defendant, the plaintiff's choice of forum should rarely be disturbed.

"Factors of public interest also have place in applying the doctrine. Administrative difficulties follow for courts when litigation is piled up in congested centers instead of being liandled at its origin. Jury duty is a burden that ought not to be imposed upon the people of a community which has no relation to the litigation. In cases which touch the affairs of many persons, there is reason for holding the trial in their view and reach rather than in remote parts of the country where they can learn of it by report only. There is a local interest in having localized controversies decided at home. There is an appropriateness, too, in having the trial of a diversity case in a forum that is at home with the state law that must govern the case, rather than having a court in some other forum untangle problems in conflict of laws, and in law foreign to itself."

138 Universal Adjustment Corp. v. Midland Bank; Kantakevich v. D., L. \& W. R. R. Co., both supra note 41; Anderson v. D., L. \& W. R. R. Co. (1940) 18 N. J. Misc. 153, 11 A. (2d) 607.

${ }^{139}$ Supra note 6, at 508, 
It is difficult to ascertain from these cases what weight, if any, actually is given to the convenience of the court in applying the doctrine. In the Gilbert case, for example, the Court examined the facts and concluded that a heavy burden would be placed on the defendant by trial in New York and that the plaintiff had shown no legitimate advantage accrumg to him from the choice of the forum. Then the Court added:

"The court likewise could well have concluded that the task of the trial court would be simplified by trial in Virginia. If trial was in a state court, it could apply its own law to events occurring there. If in federal court by reason of diversity of citizenship, the court would apply the law of its own state in which it is likely to be experienced. The course of adjudication in New York federal court might be beset with conflict of laws problems all avoided if the case is litigated in Virginia where it arose."140

Does the Court mean by this statement that even had the plaintiff shown legitimate reasons for bringing suit in New York-important witnesses residing there, for example-the district court would be upheld in dismissing the suit simply because of the difficulty of deciding Virginia law, or of solving the conflict of laws problems presented? ${ }^{141}$ Or would the Court sustain a district court in dismissing a suit between nonresidents in an otherwise convenient and appropriate forum simply because of the crowded condition of the local dockets? Or does the Court mean that convenience to the court is to be weighed in the balance with convenience to the parties, and that a plaintiff must make a stronger showing to justify his choice of a forum where the calendars of the court are congested or the foreign law would be difficult to apply? It is submitted that convenience to the court is considered only to give added weight to a decision based on convenience to the parties and that it should have no independent significance. ${ }^{142}$ "[The] ultimate inquiry is where trial will best serve the convenience of the parties and the ends of justice." 143

140 Ibid. at 511.

141 The Court has given a negative answer to that question. Meredith v. Winter Haven, supra note ith.

${ }^{142}$ See Foster, op. cit. sulpra note 1, 44 HARv. L. REv. at 58; Note (1946) 46 Coc. L. REv. $413,415, \mathrm{n}$. Convenience to the court has been specifically rejected by some courts. Cofrode v. Gartner; Mattone v. Argentina, both supra note 40; Reynolds v. Day, supra note 41.

143 Koster v. Lumbermens Mutual Co., stcpra note 42 , at 527. 


\section{B. Factors Justifying the Exercise of Discretion to Decline Jurisdiction.}

The differing attitudes of the courts as to whose interests are to be served by the doctrine of forum non conveniens have resulted in similar differences as to the standards by which the trial court's discretion is to be judged. Courts which are concerned principally with the burden on the local courts and taxpayers have established rules governing the application of the doctrine which bear little relation to the convenience of the parties or to the appropriateness of the tribunal. Other courts have established more flexible standards having the primary objective of doing justice between the parties.

\section{Where both parties are nonresidents.}

In states where convenience to the court is emphasized the basic considerations become the residence of the parties and the place where the cause of action arose. The New York courts, which will hear contract actions regardless of the residence of the parties or the inconvenience to the defendant, ${ }^{144}$ will refuse to assume jurisdiction in tort actions for personal injuries on a showing that both parties are nonresidents and that the cause of action arose outside the state. ${ }^{145}$ No inconvenience or injustice to the defendant need be shown; indeed jurisdiction may be refused even though New York is the most convenient place for the trial. In Reep $v$. Butcher, ${ }^{146}$ for example, a personal injury suit between Pennsylvania residents was brought in New York courts as a result of an automobile accident which took place in Pennsylvania but just across the New York state line. The plaintiff was hospitalized in New York and New York citizens took pictures and made measurements at the scene of the crash. Two eyewitnesses lived in Pennsylvania, but the plaintiff alleged their willingness to come to New York to testify. The court refused to accept jurisdiction of the case, saying the fact that nost of the witnesses lived in New York and that it would be a financial hardship to produce them in

144 See cases cited in notes 125,126 , supra.

${ }^{145}$ The conventional statement of the rule in the New York cases is: "It is the wellsettled rule of this state that, unless special reasons are shown to exist which make it necessary or proper to do so, the courts will not retain jurisdiction of and determine actions between parties residing in another state for personal injuries received in that state." Ferguson v. Neilson, supra note 36, at 524. Accord: Wertheim v. Clergue, supra note 124; Collard v. Beach, supra note 37; Banco De La Lacuna v. Escobar (1929) 135 Misc. 165, 237 N. Y. Supp. 267; Aly v. Alexandria Navigation Co. (1943) 43 N. Y.S. (2d) 949 ; Brandao v. United Fruit Co. (1944) 50 N.Y.S. (2d) 886.

146 Supra note 123. 
Pennsylvania was "not sufficient to warrant the acceptance of jurisdiction of litigated matters which belong solely in an adjoining state". ${ }^{147}$ Only in unusual circumstances where it is obvious that serious injustice to the plaintiff would result from refusal is the trial court upheld in assuming jurisdiction of such a suit. Therefore, if the defendant is not subject to suit, or if the statute of limitations has run where the parties reside or where the cause of action arose, jurisdiction will usually be assumed. ${ }^{145}$ And where the plaintiff is a resident of a nearby state in which the defendant cannot be served with process, the case may be heard if the plaintiff would otherwise have to travel a very great distance to sue the defendant at his domicile. ${ }^{149}$

A quite different approach is taken by courts which reject or minimize their own convenience as a basis of the doctrine. The cases here emphasize that caution should be exercised in applying the doctrine. "The rule is intended to promote justice and not to furnish an avenue of escape for those who should answer somewhere for the wrongs charged against them." ${ }^{150}$ Courts have jurisdiction of suits between nonresidents based on transitory causes of action regardless of where they arose, and this jurisdiction will be exercised unless compelling reasons exist for relegating the parties to another court. ${ }^{151}$ This atti-

\section{Ibid. at 371,27 N.Y.S. (2d) at 332.}

${ }^{148} \mathrm{In}$ an action against an unsuccessful Mexican revolutionary who absconded with government funds, the court recognized that the defendant would not be available for suit in Mexico and assumed jurisdiction, saying: "Any other rule would make this state the haven of absconders." State of Yucatan v. Argumedo (1915) 92 Misc. 547, 157 N. Y. Supp. 219. But of. Banco De La Lacuna v. Escobar, supra note 145.

Where the statute of limitations has run elsewhere so that the plaintiff will be deprived of his remedy if not allowed to sue in New York, jurisdiction will be assumed. Randle v. Inecto, Inc. (1928) 131 Misc. 261, 226 N. Y. Supp. 686; Williamson v. Palmer (1943) 43 N. Y.S. (2d) 532; cf. Anderson v. D., L. \& W. R. R. Co., supra note 138.

149 Jurisdiction was assumed when a New Jersey resident was suing a Kentucky corporation on a cause of action arising in Cahiornia, Buonanno v. Southern Pacific Co. (1923) 121 Misc. 99, 205 N. Y. Supp. 791, and where a Connecticut citizen was suing a foreign corporation which was doing business in New York on a cause of action arising in Oklahoma. Richter v. Chicago, Rock Island \& Pacific Railway Co. (1924) 123 Misc. 234, 205 N. Y. Supp. 128. See also Murnan v. Wabash Railway Co., supra note 41 ; Murnan v. Wabash Railway Co. (1928) 222 App. Div. 833, 226 N. Y. Supp. 393.

150 Overfield v. Pennroad Corp. (C. C.A.3rd, 1940) 113 F. (2d) 6, 10; see also Wilhams v. Green Bay \& W. R. Co., supra note 78; Universal Adjustment Corp. v. Midland Bank, supra note 41 , at 315, 184 N.E. at 159 ("The principle manifestly ought to be applied with caution.") ; Bethlehem Fabricators v. H. D. Watts Co. (1934) 286 Mass. 556, 190 N. E. 828, 93 A. L. R. 1124; In re Norton's Settlement, supra note 37; cf. Hagen v. Viney, supra note 41.

151 Quigley Co. v. Asbestos Ltd., supra note 41; cf. Hudson v. Von Hamm; Universal Adjustment Corp. v. Midland Bank; Tri-State Transit Co. v. Mondy, all supra note 41; 
tude was well summarized by the English court in Logan v. Bank of Scotland. ${ }^{152}$

"The Court should, on the one hand, see clearly that in stopping an action it does not do injustice, and, on the other hand, I think the Court ought to interfere whenever there is such vexation and oppression that the defendant who objects to the exercise of the jurisdiction would be subjected to such injustice that he ought not to be sued in the Court in which the action is brought, to which injustice he would not be subjected if the action were brought in another accessible and competent Court."

If there is any doubt that the plaintiff will not be able to get complete relief in another forum, jurisdiction will be assumed. ${ }^{163}$ So, where it is not clear that the defendant would be subject to the process of another court ${ }^{154}$ or that he has assets subject to levy in another jurisdiction, ${ }^{155}$ the plea will be rejected. The case will also be heard if the forum state is the only one in which jurisdiction over all proper parties can be obtained. ${ }^{156}$ And mere inconvenience to the defendant in producing witnesses or records will not justify refusal. ${ }^{157}$ The inconvenience must be serious enough to suggest a failure of justice if the suit is heard; for example, where the cost of defending is out of proportion to the amount in litigation, or the witnesses are unavailable or the production of witnesses and records would seriously disrupt a business. ${ }^{158}$

In re Norton's Settlement, supra note 37; La Societe du Gaz de Paris v. La Société Anonyme de Navigation "Les Armateurs français", supra note 35.

152 Supra note 37, at 150.

153 Anderson v. D., L. \& W. R. R. Co., supra note 138.

154 Hagen v. Viney, supra note 41, at 757, 169 So. 391 at 395: "Those entitled to and seeking it [access to the court's process] should not be compelled to resort to a species of incantation, catch as catch can, or to the practice of the arts of Delilah, to effectuate it."

155 Bethlehem Fabricators v. H. D. Watts Co., supra note 150; Standard Surety \& Cas. Co. v. Caravel Industries Corp. (1940) 128 N. J. Eq. 104, 15 A. (2d) 258; Hunter v. Wenatchee Land Co., supra note 41.

150 Overfield v. Pennroad Corp., supra note 150; see Blaustein v. Pan American Petroleum \& Transport Co. (1940) 174 Misc. 601, 21 N. Y. S. (2d) 651 ; Logan v. Bank of Scotland, supra note 37. Conversely, the fact that part of the important defendants are not subject to suit in the forum state may be a reason for declining jurisdiction. Sielcken v. Sorenson, supra note 127; cf. Koster v. Lumbermens Mutual Co., supra note 42.

$15 \pi$ See dissenting opinion of Justice Reed in Koster v. Lumbermens Mutual Co., supra note 42 , at 537 .

158 McRanie v. Palmer (D. Mass. 1942) 2 Fed. Rules Dec. 479 (not too inconvenient to bring witnesses from Connecticut to Massachusetts) ; Tri-State Transit Co. v. Mondy, suspra note 41 (no showing witnesses could not be brought from Louisiana to Mississippi); Kantakevich v. D., L. \& W. R. R. Co., supra note 41 (not too inconvemient to bring witnesses from Pennsylvania to New Jersey); Quigley Co. v. Asbestos Ltd., supra note 41 
Where the cause of action arises within a state, trial therein will usually be convenient and most courts assume jurisdiction without question even though both parties are nonresident. ${ }^{159}$ However, in a tort action between Pennsylvania residents where the accident occurred just across the state line in New York, a New York court refused jurisdiction, emphasizing the burden on the local courts and the supposed fact that it was just as convenient for the parties to sue in Pennsylvania. ${ }^{160}$ Another New York court in a substantially similar case ruled to the contrary, saying: "On principle we think the courts of this State should be open to determine causes of action in tort arising within the State and, therefore, governed by our laws." conflict has yet to be resolved by the New York appellate courts. ${ }^{102}$

\section{Where plaintiff or defendant is a resident.}

Courts which have emphasized convenience to the court as a basis for the doctrine have usually held that the bona fide residence of either the plaintiff or the defendant in the forum state at the time the cause of action arose is enough to compel the trial court to assume jurisdiction. ${ }^{103}$ When the plaintiff is a resident the courts of soine states indicate the trial court has no discretion to refuse jurisdiction; $;^{104}$ others treat the plaintiff's residence as such a strong factor in favor of exercising jurisdiction that it will usually be decisive. ${ }^{165}$ Here argu-

(New York to New Jersey) ; Robinson v. Robinson's Trustees [1930] Sess. Cas. (H. L.) 20; cf. Logan v. Bank of Scotland, supra note 37 (cost of defending out of proportion to the amount in suit).

The United States Supreme Court was divided over the strength of the showing of inconvenience which must be made by defendant in Koster v. Lumbermens Mutual Co., supra note 42 ; and Gulf Oil Corp. v. Gilbert, supra note 6 . See the discussion, infra.

159 Western Union Tel. Co. v. Phillips (1893) 2 Tex. Civ. App. 608, 21 S. W. 638; Western Union Tel. Co. v. Clark (1896) 14 Tex. Civ. App. 563, 38 S. W. 225 ; cf. Fine v. Wencke, supra note 40.

160 Gainer v. Donner, supra note 123.

101 Hunter v. Hosmer (1931) 142 Misc. 382, 383, 254 N. Y. Supp. 635, 637.

162 Malak v. Upton (1938) 166 Misc. 817,3 N.Y.S. (2d) 248; Reep v. Butcher, supra note 123 .

${ }^{163}$ In cases involving the internal affairs of foreign corporations most courts have declined jurisdiction even though the plaintiff is a resident. See authorities in note 72, supra; Universal Adjustment Corp. v. Midland Bank, supra note 41, at 314, 184 N. E. at 158.

104 Gregonis v. Philadelplia \& R. C. \& I. Co., supra note 28 ; cf. Winchester v. Browne (1890) 59 Hun. 626, 13 N. Y. Supp. 655. See Bowers, op. cit. supra note 111, at 64 .

165 The Saudades (E. D. Pa. 1946) 67 Fed. Supp. 820; Arizona Commercial Mining Co. v. Iron Cap Copper Co. (1920) 119 Me. 213, 110 Atl. 429; Wilson v. Martin-Wilson Fire Alarm Co. (1889) 149 Mass. 24, 20 N. E. 318; Cressey v. Erie Railroad (1932) 278 
ments of convenience to the court are said to be counterbalanced by the court's duty to citizens of the state who pay taxes and contribute to the upkeep of the courts. ${ }^{106}$ But if the plaintiff is not suing in his own right and a nonresident is the real party to be benefited, ${ }^{107}$ or if the plaintiff is the local administrator of a nonresident's estate whose appointment has been obtained for the sole purpose of bringing suit in the state, ${ }^{168}$ jurisdiction will be refused.

These courts also reject the plea of forum non conveniens when the defendant is a resident of the state of suit. A recent New York case said that the plea can never be presented by a resident of the forum. ${ }^{169}$ Other cases have suggested that when the defendant is a foreign corporation doing a substantial amount of business in the state jurisdiction should be assumed. ${ }^{170}$ And when the plea is presented by a nonresident defendant, the fact that a codefendant is a resident has been held sufficient to justify a court in hearing the case. ${ }^{171}$

Other courts in which the emphasis is placed on the convenience of the parties accord no such controlling significance to the residence of the parties. The Supreme Judicial Court of Massachusetts has said:

"... domestic residence of parties is not decisive in requiring courts to assume jurisdiction of a cause, but ... the basis of inquiry will be whether justice can be as well done here as in another jurisdiction to which parties may have access." ${ }^{172}$

Mass. 284, 180 N. E. 160; cf. Grovey v. Washington Nat. Ins. Co., supra note 41 ; Bowers, op. cit. supra note 111, at 64 .

166 See dissenting opinion of Justice Reed, Koster v. Lumbermens Mutual Co., supra note 42 , at 535 .

167 United States M. \& S. Ins. Co. v. A/S Den Norske A. Og A. Line (C. C. A. 2d, 1933) 65 F. (2d) 392 (an American underwriter paid the claim of a Dutch shipper and sued a Norwegian shipowner); Universal Adjustment Corp. v. Midland Bank, supra note 41 (a Massachusetts corporation was formed for the sole purpose of taking an assignment of a claim of a Russian corporation against an English bank for suit in Massachusetts); La Société du Gaz de Paris v. La Société Anonyme de Navigation "Les Armateurs français", supra note 35.

168 Hoes v. New York, N.H. \& H. R.R. Co., supra note 48 ; Pietraroia v. N. J. \& H. R. R. \& F. Co. (1910) 197 N. Y. 434, 91 N. E. 120.

169 Vigil v. Cayuga Constr. Corp. (1945) 185 Misc. 675, 54 N. Y. S. (2d) 94.

$1 \pi 0$ Quigley Co. v. Asbestos Ltd., supra note 41 ; cf. Mowat v. United Fruit Co. (1942) 37 N.Y.S. (2d) 93; Hamilton v. Berwind-White Coal Mining Co. (1945) 60 N.Y.S. (2d) 561.

171 Consumers Lumber Co. v. Lincoln (1929) 225 App. Div. 484, 233 N. Y. Supp. 530; Armor Clad Co. v. Ames (1946) 64 N. Y.S. (2d) 400.

1i2 Universal Adjustment Corp. v. Midland Bank, supra note 41, at 315, 184 N. E. at 159; see United States M. \& S. Ins. Co. v. A/S Den Norske A. Og. A. Line, supra note 167; Cressey v. Erie Railroad, supra note 165 ; Kantakevich v. D., L.\&W. R. R. Co., supra note 41. But $c f$. Trojan Engineering Corp. v. Green Mt. Power Corp. (Mass. 1936) 200 N.E. 117. 
Thus in Koster v. Lumbermens Mutual Co., ${ }^{173}$ the United States Supreme Court held that the plaintiff's residence in the forum did not compel the assumption of jurisdiction where the action was a derivative one in which the plaintiff had only a small financial stake and was not himself a witness and in which no other witnesses or records needed in the trial of the case could be found in the forum state. The factors to be considered by a trial court in applying the doctrine of forum non conveniens when the plaintiff is a resident were well formulated by the Court:

\begin{abstract}
"Where there are only two parties to a dispute, there is good reason why it should be tried in the plaintiff's home forum if that has been his choice. He should not be deprived of the presumed advantages of his home jurisdiction except upon a clear showing of facts which either (1) establish such oppressiveness and vexation to a defendant as to be out of all proportion to plaintiff's convenience, which may be shown to be slight or nonexistent, or (2) make trial in the chosen forum inappropriate because of considerations affecting the court's own administrative and legal problems. In any balancing of conveniences, a real showing of convenience by a plaintiff who has sued in his home forum will normally outweigh the inconvenience the defendant may have shown." 174
\end{abstract}

Cases may also arise when the defendant is a resident in which the plea of forum non conveniens should be allowed to avoid serious injustice. ${ }^{175}$ If, for example, a California resident brings suit in Delaware against a Delaware corporation which has its principal office and business in California on a cause of action arising in California, the plea should be available to the defendant as though suit had been brought in New York. That the technical domicile of the defendant in Delaware might be disregarded in such a case was suggested by the Court in the Koster case:

"Under modern conditions corporations often obtain their charters from states where they no more than maintain an agent to comply with local requirements, while every other activity is conducted far from the chartering state. Place of corporate domicile in such circumstances might be entitled to little consideration under the doctrine of forum non conveniens, which resists formalization and looks to the realities that make for doing justice."116

173 Supra note 42.

174330 U.S. at 524.

175 Vigil v. Cayuga Constr. Corp., supra note 169, may have been such a case. Cuban citizens were suing a New York corporation in New York on wage claims arising out of work done for the corporation in Cuba.

170330 U.S. at 527. 


\section{Procedural Rules Governing Application of Forum Non Conveniens.}

While most forum non conveniens cases have ignored the procedural questions involved in application of the doctrine, some attention has been given to the problems of fixing the burden of proof and determining when the objection must be raised. Here, again, the courts' decisions have depended on their conclusions as to whose convenience is to be served by the doctrine.

\section{Burden of proof.}

The placing of the burden of proof is of major importance in the practical administration of the doctrine. Must the plaintiff who has established the jurisdiction of the court over the parties and the subject matter of the action go further and prove to the satisfaction of the court that the forum is an appropriate one for trial of the case? Or should the defendant have the burden of establishing the factors necessary to persuade the judge to exercise his discretion to refuse jurisdiction? Courts which emphasize convenience to the court as a basis for the doctrine tend to place the greater burden on the plaintiff. Courts seldom discuss the problem in terms of burden of proof but the clear inference of the New York cases, at least, is that the defendant's burden does not extend beyond showing the nonresidence of the parties and the fact that the cause of action arose outside the statematters which usually will appear on the face of the complaint.175 Then, apparently, the burden is on the plaintiff to show "special reasons" why jurisdiction should be assumed. ${ }^{178}$ On the other hand, courts which look to the convenience of the parties in applying the doctrine place the greater burden on the defendant. The Scottish cases, for example, have been clear that the "burden of satisfying the tribunal that the case submitted to it for decision should not be allowed to proceed lies upon the defender" who must "allege weighty reasons why an admitted jurisdiction should not be exercised". ${ }^{170}$ And a num-

$17 \tau$ E.g., Ferguson v. Neilson, supra note 36; Wertheim v. Clergue, supra note 124; Gainer v. Donner, supra note 123; Brandao v. United Fruit Co., supra note 145; cf. Melvin v. Melvin (App. D. C., 1942) 129 F. (2d) 39; Brereton v. Canadian Pacific R. W. Co. (1898) 29 Ont. Rep. 57; see Blair, op. cit. supra note 33, at 33.

178 Cases cited in note 177, sucpra.

${ }^{179}$ La Société du Gaz de Paris v. La Société Anonyme de Navigation "Les Armateurs français", supra note 35, [1925] Sess. Cas. at 344. See also opinion of Lord Sumner in ibid. [1926] Sess. Cas. (H. L.) at 21; In re Norton's Settlement, supra note 37. 
ber of American cases, while not so explicit, appear to assume that the burden is on the defendant. ${ }^{180}$

The United States Supreme Court had difficulty with the problem of burden of proof in Koster v. Lumbermens Mutual Co. ${ }^{181}$ In support of its plea of forum non conveniens, the defendant in that case submitted affidavits showing that all the witnesses and records which would be required in the trial of the case were in Illinois and that tremendous expense would be involved in transporting them to the forum state of New York. The plaintiff, a resident of New York, did not deny the allegations of these affidavits nor allege any special convenience which would accrue to him through trial in New York but merely submitted a memorandum of law in which he argued that the trial court had no discretion in any event to refuse to hear the case. The majority of the Court upheld the district court in dismissing the action, saying:

"This Court cannot say that the District Court abused its discretion in giving weight to the undenied sworn statements of fact in defendant's motion papers, especially in view of the failure of plaintiff's answering affidavit to advance any reason of converience to the plaintiff. We hold only that a district court, in a derivative action, may refuse to exercise its jurisdiction when a defendant shows much harassment and plaintiff's response not only discloses so little countervailing benefit to himself in the choice of forum as it does here, but indicates such disadvantage as to support the inference that the forum he chooses would not ordinarily be thought a suitable one to decide the controversy." 182

The dissenting justices construed this portion of the opinion as holding that the defendant need only show inconvenience to himself and that then the plaintiff must show that it is to his legitimate advantage to bring suit in the particular forum. With this, the dissenters disagreed, saying: "It is the defendant's burden to convince the court that the forun is both inconvenient to it and not convenient to the plaintiff." 183.

It is submitted, however, that the problem presented to the Court was not one of burden of proof but, as the majority appeared to real-

180 Universal Adjustment Corp. v. Midland Bank, supra note 41; Standard Surety \& Cas. Co. v. Caravel Industries Corp., supra note 155 ; Kantakevich v. D., L. \& W. R. R. Co.; Quigley Co. v. Asbestos Ltd., both supra note 41. But cf. Carnegie v. Laughlin (1942) 132 N. J. Eq. 443, 28 A. (2d) 506.

181 Supra note 42.

182330 U.S. at 531.

$183 \mathrm{Ibid}$. at 535 . The dissenters also said that it "requires strong and clear proof to overcome the presumption that the place of trial is controlled by the venue statute. Mere inconvemence is not enough." 
ize, one of appellate review. The question was whether the showing made by the defendant in his undenied affidavits as to the relative convenience of the parties was so slight that it was an abuse of discretion for the trial court to dismiss the suit. ${ }^{184}$ The majority held that the defendant's showing was sufficient. The dissenters held it was not. Stressing the obvious and legitimate advantages which would accrue to the plaintiff from suit in his home state as opposed to suit in Illinois, the dissenters contended that the defendant's bare allegations that witnesses and documents would have to be brought from Illinois were not sufficient to justify dismissal without a detailed showing of the hardship involved. The basic dispute between the majority and the minority concerned the extent to which the Supreme Court should substitute its discretion for that of the district court, and the discussion of burden of proof served only to obscure that issue.

\section{When the objections must be raised.}

The cases to date have given little attention to the problem of waiving the plea of forum non conveniens. On principle it would seem that a defendant seeking dismissal of an action on the ground that trial in the forum will work an injustice should be compelled to raise the issue at least by the time of his answer. ${ }^{185}$ To allow the plea and dismiss the case after the plaintiff has gone to the expense of preparing for trial would work an umiecessary hardship on him. Emphasis on convenience to the court, however, has led the New York courts to treat the plea of forum non conveniens almost as jurisdictional. The defendant apparently may interpose the plea even after the case has gone to trial ${ }^{186}$ and the court may raise the objection on its own motion at any time, even on appeal. ${ }^{187}$

184 See notes 113-115, supra.

185 A few cases support this view. Pierce v. Equitable Life Assurance Society, supra note 36 (waived by general appearance); Western Union Tel. Co. v. Russell (1895) 12 Tex. Civ. App. 82, 33 S. W. 708 (cannot raise for first time on appeal); Morisette v. Canadian Pacific Railway Co., supra note 41 (same).

186 Waisikoski v. Philadelphia \& Reading C. \& I. Co., stupra note 53; Larrive v. Prince Line (1928) 224 App. Div. 764, 230 N Y. Supp. 217 ; Brandao v. United Fruit Co., supre note 145; of. Rothstein v. Rothstein (N. Y. Sup. Ct. 1946) 66 N. Y.S. (2d) 884, rev'd, (1947) 68 N. Y. S. (2d) 305. In Burdick v. Freeman (1890) 120 N. Y. 420, 24 N. E. 949 , the court held the plea was interposed too late when the defendant waited until the close of the trial.

187 Waisikoski v. Philadelphia \& Reading C. \& I. Co., supra note 53; Collard v. Beach, supre note 37 ; cf. Great Western Ry. Co. v. Miller, supra note 36.

The complete disregard by the New York courts of convenience to the parties as a factor in applying the doctrine is illustrated by Collard v. Beach, supro. On the first 
* * * * *

Widespread adoption of the doctrine of forum non conveniens is now possible, giving courts discretion to refuse to hear transitory causes of action whenever trial in the forum would be inappropriate. The privileges and immunities clause, which once was thought to bar application of the doctrine when the plaintiff was an individual citizen of another state, is clearly not an obstacle today. No other federal constitutional objections are seriously suggested. The current uncertainty as to the availability of the doctrine under the special venue provisions of the Federal Employers' Liability Act will, it is hoped, soon be renoved. ${ }^{188}$ And the broad approval recently given by the United States Suprene Court to use of the doctrine in the federal courts $^{180}$ should have the effect of encouraging its nore general application by the state courts.

The relative immaturity of the doctrine of forum non conveniens in America makes impossible a precise cataloguing of the factors which govern trial court discretion. Only in admiralty cases has there been any considerable body of experience with a rule giving trial courts discretion to refuse to assume jurisdiction of causes, ${ }^{190}$ and that experience has been for the most part ignored in the application of the doctrine in other types of cases. However, courts are formulating rules governing trial court discretion. It is clear that it would be held an abuse of discretion for a trial court to refuse to hear a suit brought in the state where the facts giving rise to the cause of action occurred or where the defendant has his actual domicile. The plaintiff may be denied the right to sue in the state where he resided at the time the cause of action arose only in the rare cases when his suit is so obviously vexatious and oppressive to the defendant as to far outweigh the convenience of suit at home. And all cases hold that jurisdiction

appeal, the court raised the objection that the parties were nonresidents and the cause of action foreign on its own motion, and ordered a new trial. On the retrial, the lower court denied defendant's motion to dismiss on the ground that his failure to raise the question on the first trial had caused the plaintiff to incur large expenses. On the second appeal, the court held this was a "clearly insufficient" reason for hearing the case and reversed.

188 Congressional action is possible. A floor amendment to H.R. 1639, see supra note 29 , which was intended to change that bill from one limiting venue to one making applicable the doctrine of forum non conveniens, was recently rejected by the House of Representatives. (July 17, 1947) 93 CoNG. REC. 9360, 9366. See also H. R. REP. No. 613, Part 2, 80th Cong. 1st Sess. (1947), at 4.

189 Koster v. Lumbermens Mutual Co., supra note 42 ; Gulf Oil Corp. v. Gilbert, supra note 6.

190 Many of the cases are cited in Canada Malting Co. v. Paterson Co., supra note 70, at 421, 422. The cases are reviewed in RoBnson, loc. cit. supra note 36; Coffey, loc. cit. supra note 36 . 
must be assumed if the defendant is not subject to process, or the statute of limitations has run, in the state that he claims is more appropriate.

Uncertainty as to the scope of trial court discretion arises when the defendant is subject to suit at the residence of the parties or the place where the cause of action arose, and the plaintiff brings suit in yet another state. Here the decision to assume or refuse jurisdiction must be based on a careful weighing of the facts in each case if justice is to be done. Further experience in the application of the doctrine will doubtless give rise to precedents applicable to many situations but, of necessity, definite rules for all cases can never be expressed. And some uncertainty is to be preferred to a system of rigid venue rules which, as we have seen, inevitably work injustice in many cases.

However, courts should be able to agree on the general objectives to be attained by application of the doctrine. "Convenience" and "justice" are relative terms and trial courts can intelligently apply the doctrine only if they know whose interests are to be protected. The inportance of agreement on objectives is easily illustrated. In this article the doctrine has been suggested as a device to limit the plaintiff's choice of forums in order to prevent undue hardship to the defendant without at the saine time permitting the defendant to evade or minimize his obligations. Yet the doctrine has proved a poor device for this purpose in New York where it is applied with emphasis on alleviating the burden on the local courts and taxpayers. In that state a nonresident plaintiff will frequently be denied the right to sue on a transitory cause of action even though the New York courts are those most appropriate for the trial of the action. ${ }^{101}$ In other cases jurisdiction is assumed even though the burden imposed on the defendant by trial in New York is severe and the compensating benefit to the plaintiff slight. ${ }^{102}$

Even in applying the doctrine with the objective of doing justice between the parties, courts must take care to see that the effort to minimize hardship to the defendant does not result in imposing new and unreasonable burdens on the plaintiff. Delay, particularly in per-

101 Cases cited in notes 126, 145, 146, supra; cf. cases cited in note 187, supra.

102 Cases cited in note 126, supra. The New York cases perhaps justify the following criticism of the doctrine of form non conveniens: "It may be argued that some courts are crowded, and that foreign stits are burdensome while the fees paid do not cover the cost of the suit. However, if one state shuts its courts to residents of another state, there may be retaliation by the other state. In the long run there will prohably be no gain but a loss and it would seem more desirable, on the whole, to allow free flow of litigation." GOODRICH, CONFLICT OF LAWS (1938) 15. 
sonal injury actions, favors the defendant. And the added expense and difficulties of commencing suit anew in another state may be sufficient to wipe out a plaintiff's claim. Often these factors will make outright dismissal of the suit improper. To afford relief to the defendant in such situations courts must be able to issue conditional decrees. As Foster has suggested, the basic consideration should be "whether the ends of justice might better be served by trial elsewhere, and on what terms" ${ }^{193}$ Thus the dismissal might be made conditional upon the defendant's stipulating to admit service and waive all objections to suit in the state that he considers more appropriate. To avoid unnecessary hardship to the plaintiff resulting from the delay consequent to starting a new suit the defendant might even be required to take any steps necessary to secure an expeditious trial in the other state. Still other conditions might be appropriate. And in some cases the court may find it desirable to stay the action instead of dismissing, thereby reserving power to protect the plaintiff if the defendant repudiates his stipulations in the foreign court. ${ }^{194}$ Furthermore, the burden in every case should be placed squarely on the defendant to make a detailed factual showing that the inconvenience to him of trial in the forum far outweighs the convemience to the plaintiff. Mere general allegations that witnesses and documents inust be transported from a distant state should not suffice, since mdividuals and corporations who choose to do busmess in many states will probably be put to such inconvenience wherever suit is brought and that fact should not permit thein to mimimize their obligations. ${ }^{195}$

193 Foster, op. cit. sucpra note 1, 44 HARv. L. REv. at 50. (Italics supplied.)

104 For a fuller discussion of this idea see Foster, ibid. No cases imposing conditions on a dismissal under the doctrine of forum non conveniens have been found; however, the English and Scottish courts sometimes stay actions rather than dismiss them. See GBBB, op. cit. supra note 35 , at 228 .

An even more desirable alternative to dismissal of the suit may be available in the federal courts if the revision of the Judicial Code now pending in Congress is passed. H. R. 2055, 80th Cong. 1st Sess. (1947) §1404 (a) provides: "For the convenience of parties and witnesses, in the interest of justice, a district court may transfer any civil action to any other district or division where it might have been brought." The committee report states that this was drafted "in accordance with the doctrine of forum non conveniens, permitting transfer to a more convenient forum, even though the venue is proper". H. R. REP. No. 308, 80th Cong. 1st Sess. (1947), at A132.

${ }^{105} C f$. the dissenting opinion of Justice Black in Gulf Oil Corp. v. Gilbert, supra note 6, at 515: "For any individual or corporate defendant who does part of his business in states other than the one in which he is sued will almost invariably be put to some inconvenience to defend himself. It will be a poorly represented multistate defendant who cannot produce substantial evidence and good reasons fitting the rule now adopted 
The modern rules of venue and jurisdiction have been designed to give a plaintiff every reasonable opportunity to recover for his wrongs. He should be denied the right to sue on a transitory cause of action in a court with jurisdiction over the parties only on a clear showing that he is abusing those rules for the purpose of vexing and harassing the defendant. Caution must be exercised in every case if the plea of forum non conveniens is not to become a powerful weapon in the hands of the defendant who is seeking to avoid his obligations.

by this Court tending to establish that the forum of action against him is most inconvenient." See also dissenting opinion of Justice Reed in Koster v. Lumbermens Mutual Co., supra note 42, at 536. 